\title{
The Core Of An Uneasy Case For Judicial Review
}

\section{Citation}

Richard H. Fallon, The Core Of An Uneasy Case For Judicial Review, 121 Harv. L. Rev. 1693 (2008).

\section{Published Version}

http://www.harvardlawreview.org/media/pdf/fallon_judicialreview.pdf

\section{Permanent link}

http://nrs.harvard.edu/urn-3:HUL.InstRepos:11222677

\section{Terms of Use}

This article was downloaded from Harvard University's DASH repository, and is made available under the terms and conditions applicable to Open Access Policy Articles, as set forth at http:// nrs.harvard.edu/urn-3:HUL.InstRepos:dash.current.terms-of-use\#OAP

\section{Share Your Story}

The Harvard community has made this article openly available.

Please share how this access benefits you. Submit a story.

Accessibility 


\title{
HARVARD LAW REVIEW
}

(C) 2008 by The Harvard Law Review Association

\section{ARTICLE \\ THE CORE OF AN UNEASY CASE FOR JUDICIAL REVIEW}

\author{
Richard H. Fallon, Jr.
}

\section{TABLE OF CONTENTS}

I. WALdRon's ARgument that OUtCOME-RELATED REASONS ARE INADEQUATE TO SUPPORT JUDICIAL REVIEW ........................................................ I 70 I

A. Waldron's Assumptions ............................................................................................... I $70 \mathrm{I}$

B. Which Assumptions Do What Work? .................................................................... I I I

II. Preferred Rights And Outcome-Related Reasons To Support JUDICIAL REVIEW....

A. Distinguishing Errors of Underenforcement and Overenforcement of Individual Rights. I 704

B. The Limits of the Outcome-Based Case for Judicial Review: Contestable

Premises and the Burdens of Judgment ............................................................... 7 I

III. Process-Based Reasons AND Political LegitimaCy ……………………........ I 7 I 5

A. Waldron's Process-Based Argument — And Its Limits .......................................... I 7 I 6

B. Political Legitimacy and Its Sources .................................................................... $\mathrm{I} 7 \mathrm{I} 7$

C. Comparative Democratic and Political Legitimacy............................................... I 7 I 8

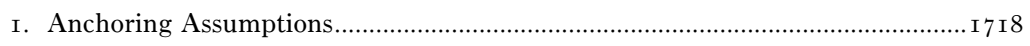

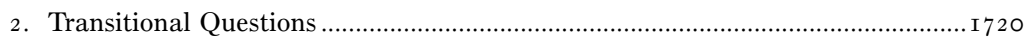

3. Judicial Review Without Entrenchment ........................................................ 1720

4. Entrenched Rights and Judicial Review ………........................................... 1723

(a) Entrenched Rights Without Judicial Review.............................................. 7723

(b) Entrenched Rights Coupled with Entrenched Judicial Review.................... 1726

IV. Notes on the Design of A System of Judicial Review ………………........ I 728

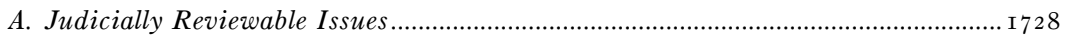

B. Scope of Review ....................................................................................... 1732

C. Choosing Strong or Weak Judicial Review ............................................................. I 1733

D. Judicial Review in Societies that Are Not Well Ordered........................................ I 1734

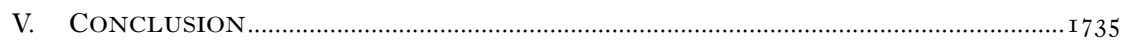




\title{
THE CORE OF AN UNEASY CASE FOR JUDICIAL REVIEW
}

\begin{abstract}
Richard H. Fallon, Jr.*
The best case for judicial review in politically and morally healthy societies does not depend (as is commonly believed) on the idea that courts are more likely than legislatures to define vague rights correctly. It rests instead on the subtly different ground that legislatures and courts should both be enlisted to protect fundamental rights and, accordingly, that both should have veto powers over legislation that might reasonably be thought to violate such rights.

In developing this case for judicial review, Professor Fallon proceeds by confronting recent, influential, philosophically probing arguments against judicial review by Professor Jeremy Waldron. Professor Fallon concedes arguendo that, as Professor Waldron argues, courts are no better than legislatures at defining rights correctly, but maintains that the crucial question is not whether courts or legislatures are less likely to err, but which kinds of errors are most important to avoid - those that result in rights being overprotected or those that result in rights being infringed. Insofar as judicial review can be designed to prevent errors in just one direction, involving failures to protect rights adequately, then judicial review may be supportable even if courts are no better than legislatures at identifying rights correctly. Professor Fallon also argues, contra Professor Waldron, that judicial review can actually contribute to the political legitimacy of an otherwise democratic scheme of government when the demands of political legitimacy are understood correctly.

Professor Fallon's revised justification for judicial review, which does not presume courts to be better than legislatures at identifying fundamental rights, has important implications for how judicial review should be practiced. It implies a diminished role for courts in cases in which fundamental rights are pitted against one another, such that the overenforcement of one entails the underenforcement of the other. It also implies that courts should withhold review when legislatures conscientiously seek to protect one fundamental right without plausibly threatening another.
\end{abstract}

$\mathrm{F}$ or a long season, the desirability of judicial review of legislation was a complacent assumption of American constitutional, political, and moral thought. A vigorous debate percolated about how courts should interpret the Constitution, but not much serious discussion addressed whether judicial review should exist at all. Now matters have changed. Although debate continues concerning how courts should make constitutional decisions, distinguished critics have begun to argue for a fundamental rethinking of the role of courts in a democ-

* Ralph S. Tyler, Jr. Professor of Constitutional Law, Harvard Law School. I am grateful to Heather Gerken, Don Herzog, Allan Hutchinson, Daryl Levinson, Frank Michelman, Martha Minow, Warren Postman, John Pottow, Richard Primus, Eric Rakowski, Sam Scheffler, Mike Seidman, and Adrian Vermeule, and to participants in workshops at the University of Michigan Law School and UC Berkeley School of Law, for extremely helpful comments on earlier drafts. Elizabeth Barchas provided outstanding research assistance. 
ratic culture such as ours. ${ }^{1}$ Some advocate the total abolition of judicial review. ${ }^{2}$

Having heard the critics, I now believe that the affirmative case for judicial review needs to be partially revised if judicial review is to be defended successfully on the moral high ground of liberal political theory. In a nutshell, the best case for judicial review in politically and morally healthy societies does not rest (as has often been asserted) on the idea that courts are more likely than legislatures to make correct decisions about how to define vague rights of the kind commonly included in bills of rights - on notions, for example, that courts are peculiarly well designed to function as "forum[s] of principle." 3 The best case, as Frank Cross also has argued, ${ }^{4}$ rests instead on the subtly different ground that legislatures and courts should both be enlisted in protecting fundamental rights, and that both should have veto powers over legislation that might reasonably be thought to violate such rights.

A suggestive, albeit not perfect, analogy comes from the federal jury system in criminal cases, under which a defendant cannot be convicted without the unanimous agreement of the jury, ${ }^{5}$ and each of the twelve jurors must vote to acquit unless persuaded that the defendant has been proven guilty "beyond a reasonable doubt." ${ }^{6}$ If the concern

\footnotetext{
1 See, e.g., Larry D. Kramer, The People Themselves: Popular ConstitutionALISM AND JUDICIAL REVIEW (2004).

2 See, e.g., Mark Tushnet, Taking the Constitution Away from the Courts I54-76 (I999).

3 See Ronald Dworkin, A Matter of Principle 69-7 I (1985) (characterizing the Supreme Court as "the forum of principle").

4 Frank B. Cross, Institutions and Enforcement of the Bill of Rights, 85 CORNELL L. REV. I529, I576 (2000) (arguing that judicial review may be justified even if a judiciary lacks "any intrinsic advantage in constitutional interpretation and enforcement" because "adding an additional check on government action will enhance the liberty the Bill of Rights offers").

5 The analogy of multiple jurors having vetoes to the vetoing effect of judicial review is admittedly not perfect. Whereas the Supreme Court can conclusively nullify an enactment that it believes to be unconstitutional (at least in the absence of a constitutional amendment), a single dissenting juror cannot absolutely block a conviction, due to the possibility of a retrial in which a conviction might subsequently be obtained. But see Jeffrey Rosen, After 'One Angry Woman,' I998 U. CHI. LEGAL F. I79, I9I (reciting conclusions of a study in which "[o]nly 34 percent of [hung jury cases were] actually retried" and asserting that among "I I-to-I hung-jury cases that are retried, juries convict only 58 percent of the time, hanging again or acquitting in 42 percent of the cases" (emphases omitted)). In addition, where judicial review operates as a safeguard only of the interests that would be harmed by a legislative enactment, the requirement of jury unanimity applies to what otherwise would be majority decisions to acquit, as well as to convict, a defendant. See Jason D. Reichelt, Standing Alone: Conformity, Coercion, and the Protection of the Holdout Juror, 40 U. MICH. J.L. REFORM 569, 570 (2007) "'The federal criminal trial system and every state, with the exception of two, require unanimous verdicts for conviction or acquittal in felony trials.").

6 See In re Winship, 397 U.S. 358, 363 (1970) (quoting Davis v. United States, I60 U.S. 469, $493(\mathrm{I} 895))$
} 
were simply to get correct judgments about whether the accused had committed a crime, decisions by majority vote, pursuant to a preponderance of the evidence standard, would produce more accurate outcomes. $^{7}$ Instead, we skew the system in a pro-defendant direction based on the premise that errors resulting in mistaken convictions of the innocent are morally worse, and thus more important to avoid, than erroneous acquittals of the guilty. ${ }^{8}$ In other words, we care less about minimizing the overall number of errors than about minimizing the errors in a particular direction - a situation that might also obtain with respect to judgments involving individual rights. ${ }^{9}$

In developing this case for judicial review, my argument proceeds by confronting and then refuting the most profound challenge to judicial review that has achieved prominence in the law reviews - Jeremy Waldron's argument in The Core of the Case Against Judicial Review. ${ }^{10}$ In that article, Waldron first debunks what he calls the "outcome-related" argument on which he takes the affirmative case for judicial review to depend - the argument that courts are more likely than legislatures to identify individual rights correctly. In any reasonably democratic society that satisfies four "quite demanding" 11 but "not unrealistic" 12 conditions, ${ }^{13}$ he argues, there is no reason to think courts more likely than legislatures to determine unerringly what rights people actually have ${ }^{14}$ (on the assumption, which I too shall adopt for purposes of this Article, that debates about constitutional rights at bottom are or ought to be debates about moral rights). ${ }^{15}$ The most important of these conditions are that legislators take questions involving individual rights seriously and that "reasonable disagreement" exists about their correct resolution. ${ }^{16}$ (Waldron does not chal-

7 See Larry laudan, Truth, Error, and Criminal Law: An Essay in Legal EPISTEMOLOGY 29-30 (2006) (examining traditional principles of criminal law to show that standards such as the requirement of proof beyond a reasonable doubt are designed to ensure that errors "will be predominantly false acquittals rather than false convictions").

8 See id. at 63 (collecting authorities that so assert).

9 See Cross, supra note 4, at $5_{592}$ (arguing that "false negatives (underenforcement of constitutional freedoms) are both more serious and more likely to occur than false positives (overenforcement of constitutional freedoms)" and calling "for a decision rule that does not necessarily minimize all mistakes but rather minimizes false negatives").

10 Jeremy Waldron, The Core of the Case Against Judicial Review, I I5 YALE L.J. I346 (2006) [hereinafter Waldron, The Core Case]. Waldron has advanced similar arguments before, see, e.g., JEREMY WALDRON, LAW AND DISAGREEMENT 2 I I-3 I 2 (I999), but he writes in the most recent article, "I am not satisfied that I have [previously] stated in a clear and uncluttered way what the basic objection [to judicial review] is." Waldron, The Core Case, supra, at $\mathrm{I}_{352-53}$.

11 Waldron so characterizes them. Waldron, The Core Case, supra note io, at I40I.

$12 \mathrm{Id}$. at $\mathrm{I} 4 \mathrm{O} 2$.

13 For discussion of those conditions, see infra Part I.

14 Waldron, The Core Case, supra note io, at 1360.

15 See id. at $\mathrm{I} 367, \mathrm{I} 385-86$ \& n.I Io.

16 See id. at I364-69. 
lenge judicial review of action by executive and bureaucratic officials, ${ }^{17}$ who may often have less opportunity for debate and deliberation before they must act in ways that might put rights at risk.) When these conditions are met, Waldron maintains, the fact that courts and legislatures differ in their assessments provides no ground for thinking courts more likely to be right.

This much of Waldron's argument I am inclined to accept, at least for the sake of argument. Many if not most arguments that courts should be presumed better than legislatures at determining whether legislation violates individual rights have a troublingly elitist cast especially if one follows Waldron in assuming that the kinds of rights commonly incorporated into bills of rights are moral rights. Virtually without exception, judges and Justices are well-educated members of the upper or upper-middle classes who have been socialized to accept professional norms. ${ }^{18}$ The preference for having a small number of lawyers in robes resolve contested questions about individual rights almost inevitably reflects one or another species of antipopulism, ${ }^{19}$ frequently coupled with highly idealized portraits of the few who wield judicial power.

In expressing unease about the elitism implicit in traditional defenses of judicial review, I do not mean to suggest that courts have no institutional advantages in resolving disputed rights questions. ${ }^{20}$ Perhaps most important, processes of judicial review can be and often are structured to permit courts to address challenges to the constitutionality of legislation only after potentially unforeseen implications have manifested themselves. Even in cases in which the passage of time and the accrual of further information help, however, judicial decisions could be made subject to legislative override, with the effect that this particular judicial advantage would largely disappear. ${ }^{21}$

Moreover, the judicial branch may labor under some relative disadvantages too - at least if we assume that judicial review will be practiced more or less as it traditionally has been. As Waldron points out, courts have an understandable tendency to confront issues that

\footnotetext{
17 See id. at $1353-54$.

18 See John Ferejohn, Independent Judges, Dependent Judiciary: Explaining Judicial Independence, 72 S. CAL. L. REV. 353, 369 (I999) (noting that judges "are likely to bring to their work the perceptions of an upper middle class, educated, largely male, and largely white elite"); see also Paul Brest, Who Decides?, 58 S. CAL. L. REV. 66I, 664 (I985).

19 See Kramer, supra note I, at 24I-46; Richard D. Parker, "Here, The People RULE” 56-58 (I994).

20 Waldron does not maintain the contrary. See Waldron, The Core Case, supra note io, at I 376.

21 Waldron acknowledges that courts may have an initial advantage in assessing as-applied challenges to legislation, but he apparently believes that the balance of argument supports only a "weak" form of judicial review in which a court may declare that important issues of rights are at stake, while leaving responsibility for resolving those issues with the legislature. Id. at I370.
} 
are fundamentally moral in legalistic, logic-chopping terms in which head-on engagement with the contending moral considerations often is almost wholly washed out. ${ }^{22}$ Roe v. Wade ${ }^{23}$ stands as Exhibit One for this proposition, ${ }^{24}$ but other examples abound.

In response to claims that courts often grapple clumsily with appeals to moral principle, some would undoubtedly reject Waldron's premise that the kinds of rights included in bills of rights typically are moral rights, not historically bounded references to be interpreted in accord with the original understanding of constitutional language. But he advances a general philosophical argument, not one about the merits of originalism as an American constitutional theory, and his challenge deserves to be answered on its own terms. In any event, constitutional adjudication in the United States has enough nonoriginalist elements that Waldron's arguments bear on U.S. practice and on whether that practice ought to be reformed even if - as I agree U.S. courts do not regard constitutional rights entirely as moral rights.

Having dismissed the outcome-based case in favor of judicial review, Waldron advances "process-based" arguments purporting to establish that judicial review is unfair and "illegitimate" in any society in which his four conditions hold. ${ }^{25}$ In essence, he claims that judicial review deprives political majorities of the right to democratic selfgovernance on important issues. This process-based objection might possibly be overcome, he acknowledges, if courts were likely to be better than legislatures at resolving disputed questions about moral rights. ${ }^{26}$ But having adjudged the outcome-related case for judicial review to be "at best inconclusive" 27 in societies defined by his four assumptions, Waldron concludes that the process-based or legitimacy argument in favor of majority decision by legislatures ought to prevail and that judicial review should be abolished. ${ }^{28}$ If judicial review could ever be defended successfully, he argues, it would need to be as a corrective for "pathologies" in a society's culture or political system. ${ }^{29}$

Waldron is a distinguished political theorist. He has no partisan ax to grind. His claims have achieved influence already, and they will undoubtedly prove influential in the future. 
As I shall demonstrate, however, a fallacy pervades The Core of the Case Against Judicial Review. Even if courts would be no more likely than the legislature to decide questions of individual rights correctly in a society in which legislators took rights seriously, Waldron's conclusion that outcome-based reasons fail to support judicial review would not follow. As I have suggested, his argument would not go through if some rights deserve to be protected by multiple safeguards or veto powers. If errors of underprotection - that is, infringements of rights - are more morally serious than errors of overprotection, and if a few other plausible conditions obtain, then there could be outcome-related reasons to prefer a system with judicial review to one without it.

Waldron's process-based argument also collapses insofar as there are outcome-related reasons to support judicial review. The fairness of procedures depends crucially on the ends that they seek to accomplish. If judicial review promotes morally better outcomes than would exclusive legislative definitions of disputed rights, then reliance on judicial review is not unfair, nor does it, as Waldron maintains, necessarily lack "legitimacy."30

As Waldron uses the term, a political regime is legitimate insofar as its design and composition provide good reasons for those who disagree with particular laws and decisions nevertheless to respect and obey them. ${ }^{31}$ In arguing against judicial review, Waldron frequently equates "political legitimacy" with "democratic legitimacy." When decisions emerge from processes in which everyone has a voice and a vote, he argues, even the losers have reason to accede to the outcome on the ground that their views were fairly taken into account. ${ }^{32} \mathrm{Al}-$ though Waldron is correct that democratic legitimacy is important, he fails to acknowledge that political legitimacy — which is a broader concept - can have multiple sources. Even if judicial review is relatively lacking in specifically democratic legitimacy, one good reason for citizens to respect political decisions with which they disagree is that those decisions issue from institutions that are well designed to safeguard individual rights. If judicial review reduces the likelihood that important rights will be infringed, then it may actually enhance, rather than undermine, a governmental regime's overall political legitimacy.

Although my arguments against Waldron add up to an affirmative case in favor of judicial review, my defense is sufficiently qualified and contingent to qualify as "uneasy." I argue that if certain conditions exist - as I am inclined to believe that they do and as Waldron does not demonstrate to be impossible or even unlikely — then judicial review

\footnotetext{
30 See id. at I386-93.

31 See id. at I386-87.

32 See id. at I386-89.
} 
would be desirable. Among the most centrally important premises supporting the case for judicial review are these: (I) Even if courts are not better overall at identifying rights violations than are legislatures, courts have a distinctive perspective that makes them more likely than legislatures to apprehend serious risks of rights violations in some kinds of cases. (2) Legislative action is more likely to violate fundamental rights than legislative inaction. (3) Some rights are more important than others and, accordingly, are more deserving of protections against infringement. (4) A system of judicial review can be so designed that the moral costs of such overenforcement of rights as judicial review would produce will likely be lower than the moral costs that would result from such underenforcement of rights as would occur in the absence of judicial review.

Although I would guess that all of these premises are satisfied in most western liberal democracies, I do not attempt to prove that they actually hold, either in the United States or elsewhere - a job that would be Herculean at the very least. In this Article it will be enough if I can, first, develop a case for judicial review that does not depend on the premise that courts are more likely than legislatures to define rights correctly and, second, call attention to the kinds of assumptions on which I believe that any argument either for or against judicial review needs to depend. I shall also, near the end, venture some thoughts on how the case for judicial review that I make in this Article would influence the form that judicial review ought to take.

The Article unfolds as follows. Part I lays out Waldron's argument that the balance of outcome-related reasons provides inadequate support to justify judicial review in nonpathological societies. Part II then criticizes Waldron's reasoning about the balance of outcome-related considerations and, in the course of doing so, develops an affirmative case for judicial review. Assuming for the sake of argument that judicial review would not increase the number of cases in which questions of rights were decided correctly, Part II supports judicial review as a means of minimizing the number of cases in which underenforcement occurs. Part III argues, contra Waldron, that judicial review can actually contribute to the political legitimacy of a scheme of otherwise democratic government when the demands of political legitimacy are understood correctly. Part IV offers a brief, tentative exploration of how judicial review ought to be practiced if courts were not presumed better than legislatures at identifying rights, but viewed instead as providing a potentially costly but also potentially valuable veto power over rights-threatening legislation. This Part argues that courts should exercise only the most deferential review or should even withhold review altogether in cases in which the legislature conscientiously seeks to protect one set of fundamental rights without plausibly threatening another (as may frequently happen in the United States when Con- 
gress legislates pursuant to Section 5 of the Fourteenth Amendment). Part V supplies a brief conclusion.

\section{WALDRON'S ARGUMENT THAT OUTCOME-RELATED REASONS ARE INADEQUATE TO SUPPORT JUDICIAL REVIEW}

In mounting his case against judicial review, Waldron makes four central assumptions. If these assumptions hold, he argues, then the case for judicial review will fail. ${ }^{33}$ Although I shall assume for purposes of argument that all of Waldron's assumptions obtain, it is important to state them clearly in order to understand their role in his "core case." It is also important to understand how Waldron's carefully stated assumptions relate to his other arguments that outcomebased reasons provide no clear support for judicial review.

\section{A. Waldron's Assumptions}

First, Waldron assumes that the society's democratic institutions, including its legislature, are in "reasonably good working order."34 In other words, the society has tolerably good even if not perfect institutions of political democracy.

Second, the society has a relatively well-functioning judicial system capable of applying the law in an impartial even if not perfect way. ${ }^{35}$

Third, the society believes in and is committed to protecting individual rights. ${ }^{36}$ There are few if any skeptics who regard the idea of moral rights as nonsensical. Rather, the society, or most of its members, believe that in principle questions involving claims of individual rights have correct answers.

Fourth, despite the society's commitment to the idea of individual rights, widespread, reasonable disagreement exists about what rights people have. ${ }^{37}$ For example, people disagree about whether the right to religious freedom encompasses a right to be excused from obedience to otherwise generally applicable laws, about whether freedom of speech subsumes a right to donate vast sums of speech-generating money to political campaigns, and about whether there is a right to abortion.

\section{B. Which Assumptions Do What Work?}

Given his four assumptions, Waldron believes courts no more likely than legislatures to arrive at the correct answer to questions of what

\footnotetext{
33 Id. at $\mathrm{I} 360$.

34 Id.; see id. at I36 $1-62$.

35 See id. at I363-64.

36 See id. at 1364-66.

37 See id. at I366-69.
} 
rights people have. As I have stated already, I am prepared to accept for purposes of argument Waldron's narrow conclusion that courts would be no more likely than legislatures to identify rights correctly if all of his assumptions held. (This, obviously, is a very big "if." I mean to leave open the question whether particular legislatures are in "reasonably good working order" with respect to their solicitude for rights.) Nevertheless, it is worth parsing Waldron's argument with care, for he fails to make explicit which of the premises carry which parts of the argumentative burden that The Core of the Case Against Judicial Review assumes.

On one possible interpretation, Waldron's fourth assumption, involving reasonable disagreement about the content of rights, does most or all of the work of establishing that courts could not be better than legislatures at deciding correctly what rights people have. If people reasonably disagree about rights, we might interpret Waldron as arguing, then we must explain not only how they disagree, but also how it is reasonable for them to disagree; and if disagreement is reasonable because no epistemically reliable method of identifying rights exists, as he may seem to suggest, ${ }^{38}$ then it is impossible to say that one decisionmaker is more likely than another to decide correctly. In short, once the reasonableness of disagreement is acknowledged, it follows inexorably that there can be no outcome-related reason to support judicial review.

Although it is possible to imagine an opponent of judicial review relying on the assumption of reasonable disagreement in this way, I do not understand Waldron to do so in The Core of the Case Against Judicial Review. ${ }^{39}$ Waldron states his four assumptions early on, but when he later considers and rejects three arguments that courts might be better than legislatures at identifying rights - that courts are likely to do better (I) because courts focus their deliberations on concrete cases, not abstractions, (2) because courts have special competence in interpreting legal texts such as bills of rights, and (3) because courts carry an obligation to provide reasoned explanations of their decisions $^{40}$ - he nowhere suggests that reasonable disagreement suffices to defeat these arguments. Rather, assuming that questions involving rights have correct answers, he maintains that claims for courts' comparatively greater competence fail either because courts do not in fact

\footnotetext{
38 See id. at 1368 (assuming "that our condition is not one in which the truth of the matter [about moral questions] discloses itself in ways that are not reasonably deniable").

39 This may be Waldron's position in other writing. See, e.g., Jeremy Waldron, The Irrelevance of Moral Objectivity, in NATURAL LAW THEORY I 58 (Robert P. George ed., I992).

40 See Waldron, The Core Case, supra note 10, at 1379-86. See also Cross, supra note 4, at I536-50 (criticizing these traditional defenses of judicial review).
} 
possess specifically asserted advantages or, alternatively, because any judicial advantage is offset by a judicial disadvantage. ${ }^{41}$

Nor do I believe that the mere fact of reasonable disagreement could persuade anyone who was not a rights-skeptic of the impossibility of one institution's being better than another at getting the right answer to questions involving individual rights. ${ }^{42}$ For me to believe that reasonable disagreement about rights is possible, while continuing to believe in a nonskeptical way that people nevertheless possess particular rights, I have to believe that I have identified the pertinent moral truth in a relatively, even if not perfectly, epistemically reliable way. If, for example, I am a utilitarian, then I must believe in the relative reliability of the processes of reasoning that led me to adopt utilitarianism in preference to Kantianism and other rival theories - even if many reasonable people disagree in light of what John Rawls called the "burdens of judgment" that inescapably attend this conclusion..$^{43}$ Similarly, if I think that the facts are pertinent to some or all moral judgments, yet believe nonskeptically in the validity of some claims of moral right, then I must think that there is a relatively epistemically reliable way of determining the relevant facts.

It lies far beyond my ambition in this Article to identify which moral theory, if any, is correct, or to determine how any kind of fact would most reliably be determined. My only point here is that acknowledgment of reasonable disagreement does not preclude reasoned judgments about what is right and wrong or about how rights are most reliably identified. And from this point, another follows: If people can reasonably believe not only that there are truths about rights, but also that there are relatively epistemically reliable means of discovering those truths, then the fact of reasonable disagreement cannot, by itself, prove that one institution could not be better than another at reaching correct outcomes. If, for example, courts routinely reasoned from better supported moral premises or used more reliable delibera-

41 Among the advantages of legislatures, he includes their tendency to focus directly on underlying moral considerations, see Waldron, The Core Case, supra note Io, at I384-85, whereas courts become preoccupied with issues of textual exegesis and interpretive methodology, see id. at I38I82 .

42 Waldron's core case against judicial review involves societies in which the rights-skeptical position is merely "an outlier." $I d$. at $\mathrm{I}_{3} 65$.

43 John RaWls, Political Liberalism 54-58 (I993). Rawls used the term to refer to "the many hazards involved in the correct (and conscientious) exercise of our powers of reason and judgment," $i d$. at 56 , which give rise to "reasonable disagreement," $i d$. at 55 , and explain why "it is not to be expected that conscientious persons with full powers of reason, even after free discussion, will all arrive at the same conclusion," $i d$. at 58 . To say that a decision is subject to the burdens of judgment is not to say that there can be no right answer, see id. (noting that some reasonably disputable judgments "may be true"), but it is to acknowledge that knock-down arguments cannot always be expected. 
tive procedures than did legislatures, then courts could be expected to reach more accurate conclusions. ${ }^{44}$

On a better interpretation of Waldron's argument, his first and third assumptions - that legislative institutions are in reasonably good order and that the society and its members, including its legislators, are seriously committed to protecting individual rights - must do the principal work of supporting his conclusion that there is no sufficient outcome-based reason to want judicial review. On this interpretation, the key point is that judges have no greater capacity for moral insight, nor do they follow processes of deliberation more likely to lead them to insight, than morally conscientious legislators.

\section{PREFERRED RIGHTS AND OUTCOME-RELATED REASONS TO SUPPORT JUDICIAL REVIEW}

As I have said, I shall stipulate for purposes of argument that if Waldron's first and third assumptions were to hold, and that if the sole question were whether courts or legislatures are more likely to identify rights correctly, there would not be sufficient outcome-based reasons to adjudge courts conclusively better than legislatures. ${ }^{45}$ Crucially, however, whether courts or legislatures will do better at identifying moral rights correctly is not the sole question to be resolved in arguing for or against judicial review. Once an alternative question is put on the table, involving whether one or both institutions should be charged with rights protection, Waldron's argument loses its potency, and a powerful variant on the traditional case for judicial review emerges.

\section{A. Distinguishing Errors of Underenforcement and Overenforcement of Individual Rights}

Although judicial review permits courts to invalidate legislation, it ordinarily imposes no impediment to the legislature's respecting or protecting individual rights by refraining from actions that it thinks would violate them. In so saying, I put to one side the well-known argument of James Bradley Thayer that the availability of judicial review predictably diminishes legislatures' willingness to deliberate seriously and independently about questions involving rights. ${ }^{46}$ Within the bounds of argument that Waldron's premises define, I take

\footnotetext{
44 I do not mean to suggest that only moral realists, who believe in objectively right answers to moral questions, could have good reasons to support judicial review. As I shall explain below, relativists or pragmatists could also be warranted in favoring judicial review.

$45 \mathrm{My}$ actual view is that courts would be more likely to reach correct decisions at least about whether general legislation violates individual rights as applied to particular cases, some of which the legislature may not have anticipated.

46 See James B. Thayer, The Origin and Scope of the American Doctrine of Constitutional Law, 7 HARV. L. REV. I29, I55-56 (I893).
} 
Thayer's view to be ruled out by the assumption that a society's democratic institutions, including its legislature, take rights seriously. Quite apart from argumentative stipulations, it would seem to me to be dramatically imprudent for a society that thought its legislature did not currently take rights seriously to abolish judicial review in hopeful anticipation that the legislature would thereafter change its ways. ${ }^{47}$

In any event, if we assume that the prospect of judicial review creates no ex ante impediment to a legislature's respecting individual rights, the question to be addressed in assessing judicial review is not necessarily whether courts or legislatures would perform better at identifying rights if we had to charge only one institution with this task. The question, instead, is whether a society might have good outcome-related reasons to enlist both the legislature and the courts in protecting individual rights. ${ }^{48}$ Or, to put the question slightly differently, might a society reasonably want to create multiple veto points so that governmental action could not occur if either a court or the legislature thought that the action would violate individual rights? ${ }^{49}$

47 But cf. TUSHNET, supra note 2, at 66 (acknowledging that concern for the Constitution currently ranks low among congressional concerns and asserting that "this situation may have arisen in part because of judicial review"); id. at I94 (suggesting that "[p]erhaps it is time" to abolish judicial review).

48 Cf. William N. Eskridge, Jr. \& John Ferejohn, Virtual Logrolling: How the Court, Congress, and the States Multiply Rights, 68 S. CAL. L. REV. I545, I547 (1995) (arguing that "separation of powers, federalism, and judicial review foster a lawmaking regime that produces multiple opportunities for rights creation and fewer opportunities for rights negation," which results in "the multiplication of rights over time"); Douglas Laycock, Federalism as a Structural Threat to Liberty, 22 HARV. J.L. \& PUB. POL'Y 67, 75 (1998) (describing the Fourteenth Amendment's "multiple enforcement mechanisms," including the judiciary, Congress, the Executive, and the states, and the possibility that if any one branch of government took action, "the Fourteenth Amendment would be safe").

49 See Cross, supra note 4, at ${ }_{57} 6$ (explaining that "the multiple vetoes concept relies on the benefit of adding judicial review on top of congressional and executive action"). Other scholars have argued that regardless of whether courts are more likely to identify rights correctly than are legislatures, judicial review might be defended on the ground that it creates an additional barrier to the enactment or enforcement of legislation. See, e.g., Richard A. Epstein, The Independence of Judges: The Uses and Limitations of Public Choice Theory, I990 BYU L. REV. 82 7, 846 (arguing that views on judicial independence may depend on what people think about "the number of hurdles that must be crossed before the state can impose its commands on individual citizens"); Julia D. Mahoney, Kelo's Legacy: Eminent Domain and the Future of Property Rights, 2005 SUP. CT. REV. I03, I29-3I (arguing that "even if judges have inferior ability to calculate the social costs and benefits of eminent domain," judicial review can "add value" by providing "multiple veto points in rearranging property rights"); Kermit Roosevelt III, Constitutional Calcification: How the Law Becomes What the Court Does, 9I VA. L. REV. I649, I704 \& n.I82 (2005) (arguing that the "chief value of judicial review" in cases in which the court may not be better than the legislature at balancing costs and benefits is "that the judiciary may serve as a second negative, and one less susceptible to the temporary excesses of popular sentiment that can infect legislatures"). 
Systems of "strong" judicial review, which Waldron inveighs against, ${ }^{50}$ institutionalize an affirmative answer to this question. In doing so, however, they need not depend on the premise that a court is more likely than the legislature to rule correctly on whether any particular claimant truly possesses a right. Rather, a stronger case for judicial review in morally and politically nonpathological societies rests on the assumption that if either a court or the legislature believes that an action would infringe individual rights, the government should be barred from taking it.

Two analogies suggest the force of this argument. One, to which I have alluded already, comes from the jury system and the demand for unanimous verdicts in federal criminal cases. ${ }^{51}$ The reason to require unanimous verdicts - as, additionally, to apply a beyond-areasonable-doubt standard of proof $^{52}$ - is not that this requirement will maximize the number of correct determinations of whether accused persons committed alleged offenses. For that purpose, a decision by majority vote coupled with a lower standard of proof would serve better. Nevertheless, we may reasonably believe that we have a good outcome-related reason to give every juror a veto over what otherwise would be a guilty verdict and, what is more, to ask each to exercise her veto power unless satisfied that the government has proven the defendant guilty beyond a reasonable doubt. The reason, obviously, is that errors that result in the conviction of the innocent are more morally disturbing than errors that result in acquittals of the guilty. ${ }^{53}$ In light of that assessment, we have adopted a system that minimizes the most morally grievous errors, even if that system leads to more of the less grievous errors, and indeed to more total errors, than would an alternative. Just as there may be outcome-related reasons to prefer a system that minimizes erroneous convictions of the innocent, so there may be outcome-related reasons to prefer a system that minimizes violations of individual rights - even at the cost of increasing the number of cases in which individual rights claims are mistakenly upheld. ${ }^{54}$

An even closer analogy involves the multipart system of lawmaking created by the United States Constitution, which has parallels in the constitutions of some other nations. As a matter of structural design,

50 See Waldron, The Core Case, supra note Io, at I354-59 (distinguishing "strong" judicial review, which authorizes courts to nullify or modify statutes, from "weak" judicial review, under which courts can signal their concerns that statutes violate rights but cannot decline to enforce statutes on that ground).

51 See supra pp. I695-96.

52 See In re Winship, 397 U.S. 358,368 (1970)

53 See LAUDAN, supra note 7 , at 63 (collecting authorities that so assert).

54 See Roosevelt, supra note 49, at r66 I (explaining that courts may adopt decision rules in an attempt to reduce certain types of errors, rather than to "minimize the total number of errors without reference to kind"). 
the Constitution makes it difficult for majorities to legislate. Separate majorities of both houses of a bicameral legislature are required, and the President also possesses a veto power. ${ }^{55}$ The underlying premise, plainly, is that it is presumptively worse for legislation to be enacted than not enacted, largely because of the threat that legislation might violate individual rights, and that multiple veto points should therefore exist. ${ }^{56}$

55 See U.S. ConsT. art. I, § 7.

56 See, e.g., The Federalist No. 5I, at 322 (James Madison) (Clinton Rossiter ed., I96I) ("Ambition must be made to counteract ambition."); Samuel Freeman, Constitutional Democracy and the Legitimacy of Judicial Review, 9 LAW \& PHIL. 327, 352-55 (I99I).

A third analogy - on which I am inclined to place less weight, because it may tend to presuppose (rather than help to establish) the desirability of judicial review - involves a number of judicially crafted rules or doctrines embodying the premise that it is better for constitutional rights to be overenforced than for them to be underenforced. Among the best known of these is the rule of Miranda v. Arizona, 384 U.S. 436 (1966), under which a confession may not be introduced in a criminal trial unless the defendant was apprised

that he has the right to remain silent, that anything he says can be used against him in a

court of law, that he has a right to the presence of an attorney, and that if he cannot af-

ford an attorney one will be appointed for him prior to any questioning if he so desires.

Id. at 479. Miranda overenforces the Fifth Amendment's prohibition against compelled selfincrimination, for not every confession elicited in the absence of a Miranda warning would necessarily be coerced. But the Supreme Court evidently determined that it was too difficult for courts to identify impermissible coercion on a case-by-case basis, and it opted for overenforcement in preference to the underenforcement that was likely to result if the burden rested on criminal defendants to prove that their wills were overborne.

A preference for rights to be overenforced rather than underenforced also finds expression in First Amendment cases affirming that "[f]reedoms of expression require breathing space." Hustler Magazine, Inc. v. Falwell, 485 U.S. 46, 52 (I 988) (quoting Phila. Newspapers, Inc. v. Hepps, 475 U.S. 767,772 (I986) (internal quotation marks omitted)). Under the First Amendment overbreadth doctrine, for example, courts will facially invalidate statutes that apply to some constitutionally unprotected speech, such as obscenity or fighting words, but that also extend to some protected speech and are "substantially overbroad." See generally Richard H. Fallon, Jr., Making Sense of Overbreadth, IOo YALE L.J. 853 (I99I). When statutes are overbroad, courts could continue to enforce them against unprotected speech and hold them unconstitutional only as applied to speech that is constitutionally protected. But the Supreme Court has said that First Amendment rights are so precious that facial invalidation is appropriate to avert the "chilling" of protected speech, see, e.g., Bd. of Airport Comm'rs v. Jews for Jesus, Inc., 482 U.S. 569, 576 (I987), even though an overenforcement of speech rights occurs as a result. For discussion of other doctrines that deliberately "overprotect" rights based on a calculation that it is better for them to be overenforced than underenforced, see, for example, Richard H. Fallon, Jr., Judicially Manageable Standards and Constitutional Meaning, II9 HARV. L. REV. I275, I303-06 (2006), and see also Mitchell N. Berman, Constitutional Decision Rules, 90 VA. L. REV. I (2004).

If courts sometimes overenforce constitutional rights, it is at least equally true and important that they sometimes underenforce constitutional rights as well. See, e.g., Lawrence Gene Sager, Fair Measure: The Legal Status of Underenforced Constitutional Norms, 9I HARV. L. REV. I2 I 2 (1978); see also Fallon, Judicially Manageable Standards and Constitutional Meaning, supra, at I 299-303. Even when constitutional norms are judicially underenforced, however, the availability of even limited judicial enforcement will presumably result in fewer cases of rights being infringed than if sole responsibility for defining and enforcing rights were confided in the legislature. 
It bears emphasis that one need not be a moral realist in order to see the force of these analogies or to accept the argument that they support. Relativists and skeptics can, and frequently do, retain firstorder moral views - personal convictions about right and wrong on the basis of which they are prepared to act - with their relativism or skepticism pertaining only to second-order questions involving the foundations for those views. ${ }^{57}$ It is therefore wholly possible for a second-order relativist or skeptic to believe, as a matter of first-order conviction, that it is more morally troublesome for rights to be underenforced than overenforced and to support judicial review based on this judgment - just as it is possible, and indeed presumably familiar, for second-order relativists to endorse the requirements of unanimous jury verdicts and proof beyond a reasonable doubt.

Although it is reasonable in principle to believe it better to err on the side of too much rather than too little protection of rights under conditions of reasonable disagreement, an argument that supports judicial review on this basis obviously risks proving too much. If multiple vetoes are good, why stop with the legislature, the President, and the courts? Why not establish other institutions with veto powers or insist on unanimous consent before any legislation can be enacted?

Any good answer to questions such as these must have two related parts. First, a sensible balance needs to be struck. Any scheme that relies on fallible human beings to identify and enforce moral rights will bring hazards with it, including the costs of errors of over- and underenforcement. ${ }^{58}$ Under these circumstances, no sound approach could wholly discount the costs of errors in one or the other direction. ${ }^{59} \mathrm{Al}-$ though most of us think it worse to convict one innocent defendant than to let three or five or perhaps nine guilty persons go free, we do not structure the criminal process on the assumption that it would be better to let thousands escape accountability than to risk ever punishing a single innocent.

Second, in striving for a reasonable balance, the strategy of assigning vetoes to multiple institutions makes most sense insofar as the recipient institutions possess distinctive perspectives tending to make them more sensitive than others to some morally pertinent considerations. ${ }^{60}$ A reason to give the President a veto power over legislative

\footnotetext{
57 See generally ThOMAs NAGel, The LAST WoRD (I997); Ronald Dworkin, Objectivity and Truth: You'd Better Believe It, 25 PHIL. \& PUB. AFF. 87 (I996).

58 See AdRian Vermeule, Judging Under UnCERTAINTY: AN INSTITUtional TheORY OF LEGAL INTERPRETATION 255-76 (2006) (categorizing pertinent costs).

59 But cf. Cross, supra note 4 , at I $_{577-78}$ (arguing that "even a wildly incompetent court would have a constitutional benefit as a backstop to screen out unconstitutional legislation").

$60 \mathrm{My}$ argument in this paragraph parallels the argument for federal habeas corpus review of state criminal convictions advanced in Robert M. Cover \& T. Alexander Aleinikoff, Dialectical Federalism: Habeas Corpus and the Court, 86 YALE L.J. I035 (I977). The authors defend federal
} 
action is that the executive and legislative branches will likely have different, potentially valuable vantage points from which to assess competing interests and values. Similarly, a reason to give courts a veto power is that courts are likely to have a perspective that may make them more sensitive than legislatures to some possible rights violations even if the evidence on whether that perspective is better overall may indeed be "inconclusive." 61 Perhaps most obviously, courts typically decide cases upon concrete facts, some of which even highly competent legislators may not have foreseen. Furthermore, a distinguishing feature of judges' professional training and mission involves a solicitude for rights as they have historically been understood. Historic understandings may of course have been wrong in some, even many, instances. ${ }^{62}$ Nevertheless, judges' professionally ingrained instincts and processes of judgment are likely to differ from those of legislators and to be better adapted to reflecting such imperfect wisdom about the content of rights as our legal tradition embodies. ${ }^{63}$ In the context of historic understandings of and anxieties about judicial power, courts can also be asked and expected to discharge their reviewing functions with reasonable restraint.

This, then, is the core of the strongest case for judicial review in the kind of nonpathological society with which both Waldron and I are concerned: errors that result in the underenforcement of rights are more troubling than errors that result in their overenforcement, and judicial review may provide a distinctively valuable hedge against errors of underenforcement.

review not on the ground that federal courts are more likely than state courts to define constitutional rights correctly, but on the basis that jurisdictional redundancy is especially desirable because state and federal courts are likely to have different perspectives on how rights ought to be defined. Id. at I046-54.

61 Although "there are a large number of obviously nontotalitarian societies - Great Britain, New Zealand, the Netherlands, Sweden, and France, for example — that survive quite nicely without" robust, American-style judicial review, those countries tend to be less protective than the United States of claimed rights involving "criminal procedure, freedom of the press when it is irresponsible, freedom of speech for the truly evil (Nazis, Klansmen, and child pornographers, for example), and a strong separation between church and state." Frederick Schauer, Judicial Supremacy and the Modest Constitution, 92 CAL. L. REV. I045, I066 n.I00 (2004). According to Schauer, "[i]t may be wrong for the United States to be so divergent, but setting these countries out as models suggests a willingness to accept fewer defendant's rights, free speech rights, free press rights, and separation of church and state rights than exist in the United States." Id.; see also Frank B. Cross, The Relevance of Law in Human Rights Protection, I9 INT'L REv. L. \& ECON. 87, 92-93 (I 999) (concluding on the basis of empirical data that "[j]udicial independence" is "significantly associated with greater political freedom, suggesting a prominent role for the law and courts in the protection of freedom").

62 See generally Adrian Vermeule, Common Law Constitutionalism and the Limits of Reason, I07 COLUM. L. REV. I482 (2007) (skeptically probing arguments that the historic survival of common law decision rules attests to their likely wisdom).

63 See generally David A. Strauss, Common Law Constitutional Interpretation, 63 U. CHI. L. REV. 877 (I996) (defending judicial review partly on Burkean grounds). 


\section{B. The Limits of the Outcome-Based Case for Judicial Review: Contestable Premises and the Burdens of Judgment}

Having now laid out a basis for supporting judicial review, I should clarify the limits of my argument. Taking seriously Waldron's claim to have mounted a persuasive affirmative case against judicial review, I have maintained that his argument is insufficient to dislodge reasonable beliefs that there are good outcome-related reasons to support judicial review. But I have meant to hedge my argument with appeals to what it would be reasonable to believe, rather than claiming straightforwardly to have demonstrated the desirability of judicial review, because my argument depends on a number of unproven assumptions, some of which may be only implicit in what I have said so far.

Although it would mark a great advance if I could now make a clinching demonstration of the validity of the assumptions on which my argument rests, I fear that I must leave matters of proof more or less where they stand. It is important, however, that I should identify the central moral, conceptual, and empirical premises on which an argument such as mine must ultimately depend.

First, I have assumed that even if courts cannot be shown to be better than legislatures at resolving disputed rights questions, courts are likely to have a distinctive perspective, involving both a focus on particular facts and a sensitivity to historical understandings of the scope of certain rights, that would heighten their sensitivity to some actual or reasonably arguable violations that legislatures would fail to apprehend. Although this premise is obviously contestable, even critics of judicial review do not generally deny that courts have some advantages in resolving rights claims. Waldron, for example, argues only that the case for thinking courts more likely than legislatures to resolve rights disputes correctly is ultimately "inconclusive," not that it is clearly insupportable. ${ }^{64}$

Second, I have assumed that legislative action is more likely to violate fundamental rights than is legislative inaction. This is a commonly held assumption that underlies a variety of familiar governmental structures - such as bicameralism requirements and provisions for presidential vetoes - that are designed to stop political majorities from enacting their preferences as readily as possible into law. Indeed, Waldron himself speaks favorably of bicameralism as a well-advised check against "legislative pathologies" possibility of reasonable disagreement over which popular dispositions count as pathological).

\footnotetext{
64 Waldron, The Core Case, supra note Io, at 1375.
}

65 Id. at I36r \& n.47. 
Nevertheless, the assumption that governmental action is more likely to violate rights than governmental inaction is certainly open to challenge. One might contest it on the ground that a well-designed constitution would include a substantial number of "positive" rights to governmental assistance. ${ }^{66}$ Or a challenger might maintain that the realization of many important moral rights requires affirmative governmental action even if the relevant rights are not formally denominated in a bill of rights. Moreover, even if positive rights are put to one side, a risk certainly exists that judicial review could sometimes frustrate legislative efforts to protect fundamental rights, depending on how constitutions are first written and then construed.

Dred Scott v. Sandford, ${ }^{67}$ in which the Supreme Court ruled that Congress could not forbid slavery in the federal territories, offers a case in point. Waldron cites a different example, Lochner v. New York, ${ }^{68}$ in which the Supreme Court invalidated a statute setting maximum working hours for bakers. Although I am uncertain whether Lochner should be regarded as a case in which the courts stymied legislative efforts to protect fundamental individual rights, rather than simply thwarted the legislature from implementing a humane policy, the example deserves attention. In a study of the recent introduction of bills of rights and judicial review into Israel, Canada, South Africa, and New Zealand, Ran Hirschl concludes that whereas those countries' constitutional courts have "fortif[ied] and expand[ed] the boundaries of the private sphere in the context of freedom of expression and religion, freedom of movement, the right to privacy (including reproductive freedom), and formal equality,"69 they have "utterly failed to promote progressive or egalitarian notions of distributive justice in a meaningful way."70 In some instances, Hirschl writes, courts enforcing bills of rights have actually "shield[ed] the economic sphere from attempts to reduce socioeconomic disparity through regulatory and redistributive means." 11

66 See, e.g., Mark Tushnet, Social Welfare Rights and the Forms of Judicial Review, 82 TEX. L. REV. I895, I919 (2004) (describing positive rights recognized in foreign constitutions and arguing that "[t]he experience of constitutional courts around the world suggests that scholars of U.S. constitutional law would do well to rethink the conventional wisdom about the inclusion of social welfare rights in judicially enforceable constitutions"). But cf. Cass R. Sunstein, Against Positive Rights, in Western Rights?: POST-Communist Application 225, 225 (András Sajó ed., I996) (asserting that it is "a large mistake, possibly a disaster" to include positive rights in constitutions in countries transitioning from communism to a market economy).

6760 U.S. 393 (I857).

68 I98 U.S. 45 (I905); see Waldron, The Core Case, supra note Io, at I348 (making this reference).

69 Ran Hirschl, Towards Juristocracy: The Origins and COnSEquences of THE NEW CONSTITUTIONALISM I I 8 (2004).

$70 \mathrm{Id}$. at $\mathrm{I} 4$.

$71 \mathrm{Id}$. at $2 \mathrm{I} 8$. 
The lesson that emerges from Dred Scott, Lochner, and Hirschl's study - and, some would say, from recent decisions by the U.S. Supreme Court invalidating legislation enacted by Congress under Section 5 of the Fourteenth Amendment ${ }^{72}$ - is that the question whether legislative action is more likely to threaten or protect important individual rights has crucial empirical and predictive as well as moral dimensions. Much depends on the status quo, the kinds of injustices that it includes, and the likelihood of successful legislative or judicial action to correct current moral shortfalls. ${ }^{73}$

As presently advised, I believe that those designing and assessing constitutions in most western liberal democracies could reasonably assume that legislative action is more likely than inaction to violate fundamental rights. ${ }^{74}$ This judgment obviously underlies bills of rights that create negative but not positive rights - and even Hirschl, in expressing frustration that judicial review has not done much to solve problems of distributive inequality, hedges in his assessment of whether judicial review has, on balance, done more harm than good. ${ }^{75}$ Moreover, because economic regulatory and redistributive legislation of the kind involved in Lochner-era cases does not typically threaten any fundamental rights at all, it should not be assumed that judicial review will result in the invalidation of such legislation (even if the possibility cannot be rejected out of hand).

I take very seriously, however, the possibility that some categories of cases should be exempted from judicial review, or at least subjected to judicial review of only a very narrow scope. Among other things, a multiple-veto-opportunities argument in favor of judicial review has no traction in cases in which legislatures seek to promote the rights of one class of citizens without threatening the fundamental rights of another. Nor does my argument apply in zero-sum controversies in which fundamental rights are pitted against one another and the over-

\footnotetext{
72 See, e.g., Kimel v. Fla. Bd. of Regents, 528 U.S. 62 (2000) (invalidating congressional legislation expanding rights to freedom from age-based employment discrimination).

${ }_{73} \mathrm{Cf}$. Freeman, supra note 56, at 36I (noting that "whether judicial review is appropriate for a particular democratic constitution is a strategic question").

74 Cf. The Federalist No. 78 (Alexander Hamilton), supra note 56, at 469 (arguing that "the courts of justice are to be considered as the bulwarks of a limited Constitution against legislative encroachments").

75 Hirschl writes, for example, that "[w]hereas the constitutionalization of rights does have crucial importance in affirming marginalized identities and enhancing the status of individual freedoms, its independent impact on ameliorating the socioeconomic status of historically disenfranchised groups is often exaggerated." HIRSCHL, supra note 69, at I68 (emphasis added). As the italicized language indicates, Hirschl is not always clear about the relationship between his claims that judicial review has failed to advance and that it has actually thwarted interests in progressive redistribution, and his judgment of the overall balance of the costs and benefits for judicial review for disadvantaged groups frequently seems equivocal.
} 
enforcement of one entails the underenforcement of the other. I shall more fully discuss the challenge posed by such cases in Part IV.

The third, related assumption on which I have relied is that some rights are more fundamental than others and, accordingly, deserve more protections against infringement through the provision of multiple veto opportunities. This assumption is also contestable. It is at least arguable - indeed, Waldron himself has maintained in other writing - that every claim of individual right asserted against democratically enacted legislation also implicates the majority's "right" to collective self-government. ${ }^{76}$ If collective self-governance is a right, and if it stands on the same plane of moral importance as such rights as freedom of speech and religion, then there could be no sound reason to err on the side of overprotecting the rights that bills of rights customarily recite.

As I have suggested, Waldron may in fact believe that the right to self-government possesses the same moral status as many of the rights commonly listed in bills of rights. He develops an argument that emphasizes the importance of rights of democratic self-government with the term "right" used in a strongly moralized sense - in his important book Law and Disagreement. ${ }^{77}$ Interestingly, however, he places little if any weight on this argument in The Core of the Case Against Judicial Review. The reason may involve his third assumption: that the societies that come within his core case hold a serious commitment to the protection of rights that they have memorialized in a bill of rights. ${ }^{78}$ In most bills of rights, a general right of political majorities to govern themselves by processes of majority decisionmaking does not occupy the same status as fundamental individual rights protected against legislative infringement.

In any event, the view that certain core individual rights are more morally important than a general right to democratic self-government seems to me both widely held and, at the very least, reasonable. Nevertheless, to defend this view would take a very long argument that I shall not attempt here.

The fourth assumption undergirding my thesis that outcome-based arguments support judicial review is that a system of judicial review can be so designed that the total moral costs of the overenforcement of rights that judicial review would likely produce will be lower than the moral costs that would result from the underenforcement of rights that

\footnotetext{
76 See Waldron, LAW AND Disagreement, supra note Io, at 2 I 3 ; see also Roosevelt, supra note 49, at 1662 (explaining that some citizens may support judicial restraint because when a court "erroneously strikes down a valid governmental act, the American people ... have been denied the ability to govern themselves").

77 See WALDRON, LAW AND DisagreEment, supra note io, at 233-54.

78 See Waldron, The Core Case, supra note io, at I364-66.
} 
would likely occur in the absence of judicial review. This is a very large assumption, and I shall revisit it in Part IV, which considers more specifically how judicial review ought to be designed, after Part III has introduced some further pertinent considerations. For now, suffice it to say that any assumption that judicial review can be so designed that its moral benefits will exceed its costs rests on tricky assessments along at least two dimensions. It requires predictions about comparative numbers of errors and about the comparative moral costs of over- and underenforcement under circumstances in which reasonable disagreement exists both about what would count as over- and underenforcement and about what their respective moral costs would be. ${ }^{79}$ In developing my argument, I have advanced no formula for making these calculations. ${ }^{80}$

My failure to work out responses to challenges to my crucial fourth assumption might appear to concede one of Waldron's main contentions: given the difficulty of producing an analytically rigorous formula for determining whether, when, and to what extent judicial review might lead to morally better outcomes than would otherwise occur, perhaps we should just dismiss outcome-based arguments as ultimately "inconclusive." But I think not. For anyone considering whether outcome-related reasons come out for or against judicial review, three possible answers stand out: first, the balance of outcomerelated reasons supports judicial review; second, the balance of outcome-related reasons opposes judicial review; third, outcome-related concerns are sufficiently uncertain that the decision whether to have judicial review should be made on other grounds entirely. What merits emphasis is that the third conclusion is as much subject to the risks of moral and empirical error as either of the first two. If outcome-related concerns matter in principle in deliberations about whether to support or oppose judicial review, the question of comparative moral costs needs to be answered, whatever the difficulties in making the requisite calculations.

79 Other considerations also matter, including the "uncertainty costs" that exist when it cannot be known in advance whether legislation will ultimately be upheld as valid. See VERMEule, supra note 58 , at 275 . In believing that a multiple-veto-points case for judicial review must depend on a sophisticated, multifactored calculation of costs and benefits, I differ with Frank Cross, who maintains that the overenforcement of rights is so categorically preferable to underenforcement that judicial review would be desirable even if courts were "typically wrong and much less capable than Congress" in making decisions about when to uphold rights claims. Cross, supra note 4 , at $1577-78$.

$80 C f$. WALdRON, LAW AND Disagreement, supra note Io, at 252-53 (noting that instrumental arguments for choosing one or another mechanism to adjudicate claims of rights frequently commit the fallacy of "presuppos[ing] our possession of the truth about rights in designing an authoritative procedure whose point it is to settle that very issue"). 
The question of comparative moral costs is not, of course, a binary one, for a crucial variable involves the nature or scope of the judicial review that courts might practice. As I have noted, no one would think that criminal defendants should go free in every case that occasions even the smallest scintilla of doubt about the defendant's innocence. Similarly, no one would think that the rules governing judicial invalidation of legislation should mandate the striking down of every statute that could even colorably be argued to violate someone's rights.

In designing a morally defensible system of judicial review, two interrelated questions thus need to be resolved. One involves which rights and other constitutional norms the judiciary should be enlisted to enforce. A related question is how stringent judicial review ought to be in order to get the balance of moral costs and benefits into an optimal or at least a defensible alignment. For example, should courts exercise independent judgment in identifying rights violations, should they invalidate legislation only in cases of "clear mistake" by the legislature, ${ }^{81}$ or should they employ standards of review of some intermediate scope? ${ }^{82}$ Once again, I have not attempted to work out answers to questions such as these, though I shall say a bit more about them in Part IV. Instead, I have assumed that it is reasonable to believe that such questions can be resolved satisfactorily, even if not perfectly or with unanimous accord.

Although the assumptions on which my case rests are, I repeat, very large - and the case itself thus is somewhat uneasy - I believe that any persuasive case for judicial review would need to rely on assumptions that are similarly strong. Surely this is true of the familiar claim that courts are better than legislatures at resolving rights-based disputes correctly under conditions of reasonable disagreement.

To conclude, despite Waldron's argument to the contrary, it is reasonable to believe that a constitutional democracy with a well-designed system of judicial review would produce a morally better pattern of outcomes than a political democracy without judicial review, even if Waldron's four conditions hold, under circumstances that plausibly exist.

\section{PROCESS-BASEd REASONS AND POLITICAL LEGITIMACY}

Waldron's core case against judicial review also has a processbased component, ${ }^{83}$ and it, too, merits consideration and a response.

\footnotetext{
81 See Thayer, supra note 46 , at I44; see also VERMEule, supra note 58, at $270-76$ (also defending a version of the clear-mistake rule).

82 See Roosevelt, supra note 49, at I66I-63 (arguing that courts may adopt decision rules of varying levels of scrutiny based on assessments of the costs of error and the desire to minimize certain kinds of error).

83 See Waldron, The Core Case, supra note Io, at I375, I386-95.
} 
In formal terms, the analysis that I offer in this Part parallels my response to Waldron's outcome-based arguments in Part II: my criticisms of Waldron's case against judicial review add up to, or at least suggest, a qualified argument that actually supports judicial review on grounds of fairness and political legitimacy.

Although this conclusion can be stated simply, my argument in this Part is intricate, reflecting the complex interrelationships among concepts or ideals of (I) the morally best pattern of substantive outcomes, (2) procedural fairness, and (3) political legitimacy. A preliminary mapping of this Part's organizational structure may therefore prove helpful.

After briefly recounting Waldron's process-based argument against judicial review, I begin by arguing that the fairness of decisionmaking procedures depends heavily on whether they are well designed to achieve substantively good outcomes. Waldron treats issues of fairness and legitimacy as independent of any outcome-based considerations that might support judicial review - for he, of course, believes that none exists. But if judicial review reduces rights violations, this benefit is clearly relevant to the issue of fairness, and it ought to matter to legitimacy as well.

Legitimacy, however, is a less intuitive concept than is fairness. In order to show that the legitimacy of decision procedures may depend partly on their capacity to generate substantively just outcomes, it is necessary to unpack the concept of political legitimacy. In doing so, I distinguish between overall political legitimacy, which is the ultimate concern of democratic political theory, and specifically democratic legitimacy, which is a vital source of political legitimacy, but not the only one. In light of this distinction, I maintain that judicial review could contribute to the overall political legitimacy of a constitutional regime insofar as it helps to minimize fundamental rights violations, even if it lacks democratic legitimacy.

It is not enough, however, to say that judicial review might make some contribution to overall political legitimacy even if it lacks specifically democratic legitimacy, for the concern remains that at least some degree of democratic legitimacy might be necessary for overall political legitimacy. In other words, the possibility must be confronted that judicial review might so far deprive a political system of its necessary modicum of specifically democratic legitimacy as to render that system illegitimate overall. In the final section of this Part, I consider and dismiss arguments to this effect, subject to the proviso that certain assumptions must hold.

\section{A. Waldron's Process-Based Argument - And Its Limits}

Waldron's process-based argument against judicial review rests on what he characterizes as "the well-known fairness arguments" in favor 
of "the principle of majority decision." ${ }^{4}$ According to him, this is the preferred mechanism for resolving disputed issues of governmental policy "[w]hen we disagree about the desired outcome, when we do not want to bias the matter up-front one way or another, and when each of the relevant participants has a moral claim to be treated as an equal." $"$ s

If Waldron were correct that there are no good outcome-related reasons to want judicial review, his fairness arguments would carry the day. But if he is wrong about the balance of outcome-based considerations, then his fairness arguments also lose their potency. It is almost too plain for argument that the fairness of procedures depends on the nature of the substantive ends that the procedures are designed to promote. For example, it is not unfair to use nonmajoritarian voting procedures in criminal trials; to accord each juror the power to veto a guilty verdict is wholly justifiable in view of the goals of the criminal justice system. Similarly, most of us do not think it unfair to put control of interest rates and the money supply in the hands of an independent Federal Reserve Board, ${ }^{86}$ even though these matters can engender reasonable contestation. Outcome-based considerations make this allocation of power fair within the context of an otherwise largely democratic government.

\section{B. Political Legitimacy and Its Sources}

As I have written elsewhere, the term "legitimacy" admits of diverse usages. $^{87}$ Appraisals of legitimacy can occur in sociological terms, referring to prevailing public attitudes toward political authorities and, in particular, to popular dispositions to respect those authorities' claims to obedience. ${ }^{88}$ Alternatively, legitimacy can function as a moral concept, measuring whether people ought to regard a political regime, institution, or decision as having an entitlement to respect that transcends the substantive correctness of an immediate object of dispute. ${ }^{89}$ In The Core of the Case Against Judicial Review, Waldron's concern involves moral legitimacy. ${ }^{90}$

\footnotetext{
84 Id. at $\mathrm{I} 387-88$.

$85 \mathrm{Id}$. at $\mathrm{I} 388$.

86 But see Jon Elster, Don't Burn Your Bridge Before You Come to It: Some Ambiguities and Complexities of Precommitment, 8I TEX. L. REV. I75 I, I779 (2003) (noting that central banks such as the Federal Reserve "have been widely criticized for lack of democratic legitimacy").

87 See Richard H. Fallon, Jr., Legitimacy and the Constitution, I 8 HARV. L. REV. I787, I $789-90$ (2005).

88 See id. at I $795-96$.

89 See id. at I $796-\mathrm{I} 80 \mathrm{I}$.

90 See Waldron, The Core Case, supra note Io, at I387-89 (introducing the concept of political legitimacy as necessary to explain to those who disagree with political decisions why they none-
} 
No less than fairness, political legitimacy is relative to the ends that an institution seeks to achieve. One possible ground for the political legitimacy of a decision is that it emerged from open processes in which all citizens had equal voice and votes. ${ }^{91}$ But there are grounds for political legitimacy besides the majority-decision principle. Another good reason to respect a decision and to regard it as deserving obedience is that it issued from a process designed to reach generally sensible substantive decisions while making infringements of individual rights as unlikely as reasonably possible. ${ }^{92}$

When the diversity of potential sources of political legitimacy comes into view, what Waldron can claim to have established convincingly is, at most, that judicial review lacks the specifically democratic form of legitimacy that adheres to decisions reached through majoritarian processes. When other sources of political legitimacy enter the calculus, the possibility emerges that judicial review might actually promote, not detract from, the overall legitimacy of a governmental regime if it provides important assurances against rights violations.

\section{Comparative Democratic and Political Legitimacy}

In claiming that judicial review might enhance the legitimacy of a system of government, I need to introduce some qualifications. Although there are multiple possible sources of political legitimacy, democratic legitimacy matters deeply. A scheme of government that wholly lacked democratic legitimacy, such as a hereditary dictatorship, might strike us not only as seriously deficient in democratic legitimacy, but also as lacking political legitimacy more generally. This judgment might well persist even if the dictator put a number of safeguards in place to protect against violations of the individual rights that typically appear in bills of rights - except, of course, for voting and political rights. It is therefore necessary to take seriously whether judicial review sufficiently robs an otherwise generally democratic scheme of government of its democratic legitimacy that it threatens the system's political legitimacy overall.

I. Anchoring Assumptions. - Although the question whether judicial review might diminish or even demolish overall political legitimacy bears asking, it is also nebulous. No set scale for calibrating political legitimacy exists, and the standards of assessment can be at best loosely defined. I shall proceed, however, on the basis of a number of

theless ought to regard those decisions as worthy of respect and as having a moral claim to obedience).

91 See id. at $1387-88$.

92 Cf. Randy E. Barnett, Constitutional Legitimacy, io3 Colum. L. REv. I I I, I45 (2003) (asserting that "a legitimate lawmaking process is one that provides adequate assurances that the laws it validates are just"). 
assumptions, beginning with three conceptual assumptions that I mean to be neutral with respect to the legitimacy of judicial review. First, as I have signaled already, I assume that the purpose of legitimacy inquiries is to determine whether citizens have a moral reason to accede to political decisions with which they substantively disagree ${ }^{93}$ or whether government officials are morally justified in coercively enforcing the law. ${ }^{94}$ Second, I assume that in every case this question has either a yes or a no answer - that is, that it is either minimally legitimate or is not (even if there is reasonable disagreement about which answer is correct). Third, however, I assume that among minimally legitimate regimes some are more legitimate, in the sense of more closely approximating an ideal of perfect legitimacy, than are others..$^{95}$ Accordingly, judicial review might affect political legitimacy in either of two ways: it might make a political regime either legitimate or illegitimate in the minimal sense, or it might affect whether a minimally legitimate scheme of government is more or less legitimate.

Even with these anchors in place, inquiry into the legitimacy of judicial review risks cascading into self-defeating abstraction. To meet this difficulty, I shall make four additional, substantive assumptions about the political regimes to which judicial review might be added or from which it might be subtracted. Although these assumptions are deliberately chosen to make the case for the legitimacy of judicial review seem plausible, none of them, to borrow a term from Waldron, is "unrealistic." Moreover, all reflect the modest aspirations of this Article, which aims not to prove decisively that every society should adopt judicial review, but only to show that there are plausibly imaginable yet nonpathological circumstances under which judicial review would contribute to political legitimacy overall.

First, I shall assume that a system with judicial review produces fewer violations of fundamental rights than would a system without judicial review.

Second, I shall assume that a system that includes judicial review also comprises reasonably well-functioning democratic institutions, such as a legislature, with large responsibilities for the enactment of law and the design of governmental policy.

Third, I shall assume that the decision to establish judicial review emerged from a majoritarian or supermajoritarian process at Time One, even though it subsequently constrains majority decisionmaking at Time Two and thereafter.

\footnotetext{
93 See Waldron, The Core Case, supra note Io, at I386-87.

94 See Fallon, supra note 87, at 1800.

95 Id. at I 796-99 (distinguishing "ideal" from "minimal" legitimacy).
} 
Fourth, I shall assume that the citizens living at Time Two, or at least many of them, feel a psychological sense of connection to their Time One predecessors as co-participants in an enterprise of collective self-government extended over time.

2. Transitional Questions. - Although all of my anchoring assumptions are important, the third substantive assumption most directly frames the questions raised by Waldron's arguments: is it politically legitimate for democratic majorities or supermajorities at Time One to establish judicial review as one element of a multi-part system of government, notwithstanding actual or anticipated protests that judicial review is unfair because it will make it more difficult for political majorities to enact their preferences into law at Time Two? This question has many possible variants, of which I shall consider just two. First, I shall discuss the political and especially the democratic legitimacy of judicial review when judicial review is not entrenched in a society's constitution. Absent entrenchment, judicial review exists, but it could be abolished by majority vote in the legislature, which could also override any particular judicial decision. Second, I shall consider the distinct issues that arise when judicial review is entrenched in a double sense - when the rights protected by judicial review cannot be altered or abolished except by supermajoritarian procedures, and when the institution of judicial review is itself protected against abolition by mere legislative majorities.

3. Judicial Review Without Entrenchment. - If a majority of citizens in an otherwise reasonably democratic society wants to establish or maintain nonentrenched judicial review as a means of protecting nonentrenched rights, I can see no plausible objection of political legitimacy. As I have argued, judicial review might reasonably be thought to enhance substantive justice by minimizing infringements of important rights. Moreover, when judicial review is not entrenched and when it protects rights that are also not entrenched, judicial review does not so much derogate from the principle of majority decision as implement it: democratic majorities that want judicial review for outcome-based reasons are entitled to legislate accordingly.

I am not sure whether Waldron agrees with this assessment. In The Core of the Case Against Judicial Review, he states at the outset that the target of his argument is strong or entrenched, not weak or nonentrenched, judicial review. ${ }^{96}$ Later, however, he advances an argument, almost in passing, that appears to assert the unfairness of judicial review that is subject to legislative override. Even if the legislature can amend the provisions on which courts have based their decisions to invalidate legislation, it is unfair, he writes, to have a sys-

96 See Waldron, The Core Case, supra note io, at 1354. 
tem of judicial review that "will have credentials in the political culture that raise the stakes and increase the burden associated with the amendment effort" and thereby result in "the deck . . . be[ing] stacked" against those who dislike what a court has done. ${ }^{97}$

Although Waldron's passing remark should raise a red flag for anyone otherwise prepared to assume without analysis that nonentrenched judicial review is wholly immune to fairness objections, it is not easy to identify the premises on which an argument to the contrary might rest. On the strongest possible interpretation, the majoritydecision principle would condemn any rule that impedes current majorities from enacting their preferences as frictionlessly as possible into law. Although this extreme interpretation would explain a belief that even nonentrenched judicial review is politically illegitimate, the position that it reflects seems chimerical. ${ }^{98}$ Because democratic government cannot exist in the absence of rules to constitute it, decisionmakers at Time One need to be able to structure or constitute the forms of political democracy - the voting rules, the offices for which elections will be held, the requirements for the enactment of valid legislation, and so forth - that will obtain thereafter unless they are authoritatively changed. ${ }^{99}$ Moreover, virtually every electoral mechanism and rule of parliamentary procedure may have some effect in frustrating the wishes of current majorities. Why are elections so far apart? Why must so many rules and procedures - requirements of multiple readings, opportunities to prolong debate, and so forth - stand in the way of enacting a bill into law? Whether they are wise or unwise, many rules established at Time One do not so much constrain political de-

97 Id. at I394. The pertinent passage reads as follows:

$[D]$ efenders of judicial review claim that if legislators disagree with a judicial decision about rights, they can campaign to amend the Bill of Rights to explicitly override it. Their failure to do this amounts to a tacit democratic endorsement. This argument is flawed because it does not defend the baseline that judicial decisionmaking establishes. Amending a Bill of Rights characteristically involves a supermajority; or if it is a British- or New Zealand-style statute [that can be overruled by a simple legislative majority], it will have credentials in the political culture that raise the stakes and increase the burden associated with the amendment effort. If our disgruntled citizen $\mathrm{C} n$ asks why the deck should be stacked in this way, the only answer we can give her refers back to Id.

judicial decision. And that has already been found wanting.

98 See Eric A. Posner \& Adrian Vermeule, Legislative Entrenchment: A Reappraisal, ir i YalE L.J. I665, I686 (2002) (noting that "[t]he Condorcet paradox . . casts doubt on the premise that a simple majority can in normal circumstances even be identified," due to the phenomenon of cycling, in the absence of institutional structures and mechanisms of agenda control).

99 In theory, at least, there is a major puzzle about how an initiating institution such as a constitutional convention could organize itself without a prior settlement of voting rules. See JoN Elster, Ulysses AND THE SiRENS: STUdies IN RATIONALITY AND IRRATIONALITY 95 (rev. ed. 1984) (hypothesizing that in the case of an "original assembly" the "circumstances [may] make for a unity and unanimity in the face of which procedural questions evaporate"). 
mocracy as establish and empower it ${ }^{100}$ - even though the effect of some is to "raise the stakes and increase the burden" that must be borne by those wanting change.

Beyond concerns about simple coherence, ideals of democratic legitimacy need to be tested against and brought into a sensible alignment with broader ideals of political legitimacy, which presumably attach significance to the likelihood that structures of (reasonably) democratic government will produce good substantive outcomes - so that bicameralism can be preferred over unicameralism, for example, not because it is more democratic, but because it is likely to yield better legislation. To put the point slightly differently, there may be competing conceptions of democratic legitimacy. ${ }^{101}$ Given a choice, one might reasonably prefer a conception that coheres as well as possible with the best ideal of overall political legitimacy, including the concerns about substantively good government that the broader ideal imports.

On this point, Waldron would not appear to disagree with my analysis, at least in the abstract. For example, he not only assumes that bicameralism requirements accord with democratic ideals, but actually supports bicameralism on the ground that it furnishes a prudent check against possible majoritarian pathologies. ${ }^{102}$ He gives no hint, moreover, that he would withdraw his praise in cases - such as that of the Constitution of the United States - in which exacting requirements for the enactment of legislation were put into place for the purpose of stopping transient majorities from violating individual rights, notwithstanding reasonable disagreement about those rights' proper contours.

Measured against premises that Waldron clearly accepts, the argument that nonentrenched judicial review would be politically or even democratically illegitimate thus seems unpersuasive. The same conclusion emerges from reflection on the untenable implications of the premise that it is democratically illegitimate for political majorities to establish institutions "that will have credentials in the political culture that raise the stakes and increase the burden" of reversing their decisions by majority vote in the legislature. ${ }^{103}$ This premise would sug-

\footnotetext{
100 See Stephen Holmes, Passions and Constraint i34-77 (i995); Larry Alexander, What Is the Problem of Judicial Review?, 3 I AUSTL. J. LEGAL PHIL. I, 3-4 (2006).

101 See, e.g., John Ferejohn \& Lawrence Sager, Commitment and Constitutionalism, 8I TEX. L. REV. I929, I933 (2003) (noting that "[d]emocracy is an essentially contested concept"); Freeman, supra note 56, at 332-39 (criticizing a purely procedural or majoritarian conception of democracy and defending an alternative social contractarian conception that also incorporates a demand for respect for basic individual rights).

102 See Waldron, The Core Case, supra note ro, at r36r \& n.47.

103 As Posner and Vermeule argue, much ordinary legislation has the same effect:
} 
gest, for example, that it is politically illegitimate for states to vest responsibility for drawing electoral districts in unelected, nonpartisan commissions, the decisions of which could be overturned by a partisan majority in the legislature. ${ }^{104}$ As I have suggested already, reliance on a mechanism of this kind could more aptly be described as implementing decisions made by a fairly democratic process than as unfairly "stack[ing]" the "deck" against those who appeal to the principle of majority rule.

4. Entrenched Rights and Judicial Review. - If some constitutive rules of democratic government that were enacted at Time One can make it difficult for Time Two majorities to enact their preferences into law without affronting the ideal of democratic legitimacy, the question arises why, or if, entrenchment is different. If bicameralism requirements and presidential vetoes are democratically acceptable devices for protecting individual rights, then what, if anything, is so objectionable from the perspective of democratic legitimacy about Time One decisions to entrench certain rights ${ }^{105}$ - especially if the entrenchments are subject to supermajoritarian override and thus make it difficult but not impossible for Time Two majorities to enact their preferences into law? ${ }^{106}$

(a) Entrenched Rights Without Judicial Review. - Because entrenched rights could exist even in the absence of judicial review, with the legislature trusted to define and enforce them, it is an important preliminary question in considering Waldron's argument against judicial review whether he opposes all entrenchments of rights or just entrenched rights coupled with entrenched judicial review. In The Core of the Case Against Judicial Review, Waldron elides this question. ${ }^{107}$ In Law and Disagreement, however, he suggested that he finds all entrenchment to be incompatible with democratic ideals:

The Endangered Species Act imposes a political cost on later congressional majorities with different views about species protection - majorities who might be willing to allow or even promote animal takings and habitat destruction absent the Act but who are not willing to pay the price attendant upon repealing the Act to accomplish those purposes.

Posner \& Vermeule, supra note 98 , at 1696.

104 Such commissions have been proposed or established in a number of states to preserve the basic fairness of the electoral system. See generally Scott M. Lesowitz, Recent Development, Independent Redistricting Commissions, 43 HARV. J. ON LEGIS. 535 (2006).

105 For a lucid introduction to debates about this issue since the eighteenth century, see HOLMES, supra note Ioo.

106 It bears noting that entrenchment comes in degrees, reflecting differences in the obstacles that would need to be overcome at Time Two in order to displace a norm entrenched at Time One. For discussion, see infra section IV.C.

107 Waldron assumes that a society committed to rights will have a bill of rights, though he "mak[es] no assumption that the Bill of Rights is entrenched.... I want to leave that open." Waldron, The Core Case, supra note Io, at $\mathrm{I}_{3} 65$. 
To embody a right in an entrenched constitutional document is to adopt a certain attitude towards one's fellow citizens. That attitude is best summed up as a combination of self-assurance and mistrust: selfassurance in the proponent's conviction that what he is putting forward really is a matter of fundamental right and that he has captured it adequately in the particular formulation he is propounding; and mistrust, implicit in his view that any alternative conception that might be concocted by elected legislators next year or in ten years' time is so likely to be wrong-headed or ill-motivated that his own formulation is to be elevated immediately beyond the reach of ordinary legislative revision. ${ }^{108}$

Waldron's argument that entrenchment reflects a kind of insult by Time One decisionmakers directed toward their partners and successors in democratic self-governance moves too quickly. Not all entrenchments of decisions inherently involve insults. For example, individual human beings can have good, noninsulting reasons to entrench current decisions against future reversal even with respect to themselves, as illustrated by the much cited case of Ulysses and the Sirens. ${ }^{109}$

The argument that entrenchments are inherently insulting also ignores the constitutive function that constitutions sometimes perform. At Time One, it may be an open question for those drafting or being asked to assent to a constitution whether or with whom to join in a proposed project of collective self-government. ${ }^{10}$ Under these circumstances, it may not be unreasonable to seek entrenchment of assurances without which a proposed collective venture would appear unattractive or even unacceptable. When the question at issue is who "one's fellow citizens" will be, the suggestion that bargaining for entrenched guarantees reflects an unworthy "combination of selfassurance and mistrust" seems misplaced.

Any general claim that all entrenchments of rights necessarily violate the minimal requirements of democratic legitimacy seems similarly unsustainable. To begin with, some rights, such as voting and free speech rights, might actually be necessary for democratic legitimacy to exist. One source of democratic legitimacy - not the only source, but

\footnotetext{
108 WALDRON, LAW AND DISAGREEMENT, supra note Io, at 22 I-22.

109 See, e.g., ELSTER, supra note 99, at 36-37. In citing a case of individual precommitment, I do not mean to suggest that the entrenchment of norms in constitutions - in which one generation attempts to bind successor generations as well as itself - are similar in all or even most respects. I mean only to argue that attempts at precommitment do not necessarily convey an insult.

$110 C f$. Ferejohn \& Sager, supra note IоI, at I930 (noting the likelihood that "those who expected to be threatened by the new national government" created by the Constitution of the United States "insisted that certain of their rights were guaranteed, or committed to, as a price for accepting the new government").
} 
an important one - is substantive consonance with democratic ideals. ${ }^{111}$

In addition, rules adopted at Time One that make it difficult for political majorities to enact their preferences into law at Time Two may possess at least some democratic legitimacy insofar as they were themselves established through democratic processes at Time One and insofar as the citizens at Time Two regard their Time One predecessors as participants in a continuing regime of collective self-government. ${ }^{112}$ On the scale of democratic political legitimacy, it counts for something (though surely not for everything) that a rule that frustrates majoritarian decisionmaking at Time Two was itself enacted through a fair democratic process at Time One.

Finally, it matters crucially that democratic legitimacy is a property of political regimes overall, not just of their components. ${ }^{113}$ Even if one element, such as judicial review, is relatively lacking in democratic legitimacy, democratic legitimacy may remain a property of the regime as a whole - which, as I have insisted repeatedly now, may gain in political legitimacy overall by foregoing aspirations to maximize specifically democratic legitimacy in some of its elements. In a country in which robustly democratic institutions make the bulk of important political decisions, the right question about entrenchments of rights is not whether they are maximally democratic, but whether they are otherwise justified within a politically legitimate regime that derives some of its legitimacy from specifically democratic sources.

\footnotetext{
111 See Ronald Dworkin, Freedom's Law I5-34 (I996); Michael J. Klarman, Majoritarian Judicial Review: The Entrenchment Problem, 85 GEO. L.J. 49I, 499-50I (I997).

112 My way of putting this point may appear to conflate an empirical psychological issue involving how people living at Time Two view their Time One predecessors - with a fundamentally moral issue of political legitimacy. But I do not think so. The very idea of democratic legitimacy necessarily presupposes the existence of a community whose practices should at least presumptively be democratic. In considering the specifically democratic legitimacy of any claim that a rule is binding in the present because it was adopted by a majoritarian or similar procedure in the past, it always matters how those living in the present reasonably understand their connection with past actors. Most of us do not doubt the democratic legitimacy of legislation enacted by Congress in 1789 or 1889 , even though none of us was alive then, any more than we doubt the democratic legitimacy of legislation enacted by Congress in I989 or 2006 . But cf. Thurgood Marshall, Reflections on the Bicentennial of the United States Constitution, IOI HARV. L. REV. I, 2-5 (I987) (questioning "the wisdom, foresight, and sense of justice" of the Framers due to their discrimination on the basis of race and gender). By contrast, any suggestion that we were bound today by a decision reached by majority vote of the British Parliament, whether before or after the Revolution, would be wholly lacking in democratic legitimacy in the United States because the requisite sense of participation in a shared, ongoing project of democratic self-government would be absent.

113 See Frank I. Michelman, Is the Constitution a Contract for Legitimacy?, 8 REv. Const. STUD. IOI, IO5 (2003) (maintaining that legitimacy judgments appraise "an entire system, or practice, or 'regime' of government").
} 
(b) Entrenched Rights Coupled with Entrenched Judicial Review. - The strongest objection to judicial review undoubtedly involves entrenched constitutional provisions, especially those guaranteeing individual rights, that are backed by entrenched judicial review. Waldron argues forcefully that because the appropriate specification of rights may be subject to reasonable disagreement, fairness requires the resolution of disagreement by democratically accountable institutions. ${ }^{114}$

The first thing to be said about this claim - even insofar as it appeals to the ideal of specifically democratic legitimacy - is that it seems at the very least to sweep too broadly. As John Hart Ely argued, one vital function of entrenched judicial review can be to promote democratic legitimacy by ensuring that elected representatives adhere to democratic norms. ${ }^{115}$ Certainly officeholders can have incentives to enact measures tending to disable political opposition. With this hazard in view, the entrenchment of judicial review to protect the constitutive norms of political democracy could serve as a safeguard of, rather than a threat to, the democratic legitimacy of constitutional government.

In conjuring the prospect that a legislature might trample on rights of political participation or otherwise subvert democratic selfgovernment, I have of course imagined that two of the four assumptions on which Waldron rests his case against judicial review might cease to hold: a legislature that disregarded citizens' rights and concerns of democratic legitimacy would not be "in reasonably good working order," nor would it manifest a commitment to preserving rights. Accordingly, this might look like the kind of "pathological" situation in which Waldron acknowledges that judicial review might indeed be warranted. ${ }^{116}$ Moreover, because the case would come under Waldron's express exception for pathological societies, it might appear not to weaken his argument that entrenched judicial review should be rejected as democratically illegitimate in societies whose legislatures are in good order.

But this line of reasoning ignores the distinction between Time One, when a constitution is established, and Time Two, when the conditions existing at Time One may have ceased to exist. Once this distinction is recognized, it seems plain that decisionmakers at Time One might reasonably entrench judicial review of legislation alleged to threaten the constitutive norms of political democracy, not because they believe their society to be pathological at Time One, but to establish a bulwark against pathologies that might develop in the future.

\footnotetext{
114 See Waldron, The Core Case, supra note Io, at I389-93.

115 See John Hart Ely, Democracy And Distrust: A TheOry of Judicial REviEw I35-79 (I 980); see generally Klarman, supra note I I I.

116 Waldron, The Core Case, supra note io, at I352, I40I-o6.
} 
Surely a society can take precautions against the possibility of future legislative pathologies without thereby betraying itself as pathological already. ${ }^{117}$

Of course, judicial review under most constitutions aims to protect individual rights on a broad basis, not just to safeguard the constitutive norms of political democracy. Insofar as entrenched judicial review extends to asserted violations of rights not directly linked to political democracy, its claim to specifically democratic legitimacy grows weaker. But a slippage into overall political illegitimacy need not result.

Even in cases that trigger reasonable disagreement, the force of Waldron's argument erodes under the weight of a number of mutually reinforcing considerations, most if not all of which should now be evident. First, as I have emphasized, political legitimacy has sources besides democratic legitimacy. If good reasons exist to think that entrenched judicial review may produce a morally better pattern of results than would otherwise occur, then entrenched judicial review derives (some) political legitimacy from its functionality.

Second, the adoption of judicial review through relatively democratic processes at Time One may endow it with a continuing residue of democratic legitimacy at Time Two, even in cases involving reasonable disagreement about the appropriate specification of disputed rights. Recognizing once more that legitimacy is a matter of degree, I do not mean to claim that the entrenchment of judicial review is necessarily perfectly democratically legitimate at Time Two, just that democratic adoption at Time One may count for something. ${ }^{118}$

Finally, insofar as the issue is the democratic legitimacy of the political system as a whole, rather than just the corner involving judicial review, a scheme of government that includes judicial review can still register decently high even on the scale of democratic legitimacy. In assessing overall democratic legitimacy, it will matter greatly if a political regime's legislature is "in reasonably good working order" and if, as I have suggested, many exercises of entrenched judicial review may serve more to protect than to threaten political legitimacy.

When all of these considerations enter the analysis, Waldron fails to demonstrate the political illegitimacy of judicial review even in cases involving controversial applications of vague moral rights. If judicial review makes a contribution to the overall moral quality of a society's

117 Waldron himself so acknowledges when he defends a preference for bicameral over unicameral legislatures on the ground that "unicameral arrangements can easily exacerbate other legislative pathologies." Id. at I36I n.47.

118 The degree of entrenchment may also matter. Democratically established entrenchments that are subject to displacement by supermajority voting requirements may be less troublesome than are absolute or more nearly absolute entrenchments. 
political decisions, then judicial review might actually enhance the overall political legitimacy of an otherwise reasonably democratic constitutional regime.

\section{Notes on the Design of A System of Judicial Review}

In advancing a case for judicial review that rests on the desirability of multiple veto points to protect fundamental rights, even on the assumption that a well-functioning legislature takes rights seriously, I have so far simply assumed that a system of judicial review could be so designed that the moral costs of the resulting likely overenforcement of rights would be less than the moral costs of the underenforcement of rights that could be anticipated otherwise. For reasons stated above, proof of the validity of this assumption exceeds my ambitions in this Article. Nevertheless, the questions whether there should be judicial review and how judicial review ought to be designed are too intertwined for any complete separation between them to be wholly satisfactory. Before concluding, I therefore want to say a few words about how my argument in favor of judicial review - which makes no assumption that courts are better than legislatures at resolving questions of rights correctly - bears on how judicial review should be designed and administered. For purposes of exposition, I shall separately address three issues that are in fact pervasively interconnected. First, which claims of rights should courts review? Are there some issues with respect to which judicial review is unnecessary or unwise? Second, what should be the scope of judicial review, or how searching should it be? Third, should judicial review be entrenched against legislative override ("strong") or subject to legislative displacement ("weak")?

\section{A. Judicially Reviewable Issues}

Because I have rested my argument for judicial review of legislation on the premise that some rights are more fundamental than others and therefore more deserving of protection, my core case extends only to the kinds of fundamental rights characteristically protected in bills of rights and does not necessarily apply directly to "ordinary" liberty rights to freedom from governmental regulation. ${ }^{119}$ Claims of rights to

\footnotetext{
119 Although I have accepted for purposes of argument that courts are no better than legislatures at identifying rights correctly, I have not similarly assumed that courts have no comparative advantages over executive officials. Executive officials must frequently make snap, nondeliberative decisions that even they themselves might not endorse after thinking through the implications for individual rights. Judicial review of executive action thus seems to me a sound practice that my argument in no way calls into question, regardless of the nature of the rights at stake. $C f$. TUSHNET, supra note 2, at 163-64 (arguing that a system without judicial review of legislative
} 
liberty in many Lochner-era cases thus might be excluded entirely from judicial review under my argument. Alternatively, to anticipate a "scope of review" issue, judicial scrutiny might be minimal in such cases - a possibility that of course tracks current constitutional practice in the United States. ${ }^{120}$ Or courts' decisions in cases of this kind might be subject only to weak judicial review even if strong judicial review occurred in other cases.

Similarly, my argument for judicial review does not encompass cases in which the legislature enacts its interpretation of fundamental rights into law and the resulting legislation does not threaten the fundamental rights of others. ${ }^{121}$ To take an example from U.S. constitutional law, my argument for multiple veto opportunities to protect fundamental rights would ordinarily provide no foundation for judicial review of congressional action to protect congressionally defined rights under Section 5 of the Fourteenth Amendment. ${ }^{122}$ If no fundamental rights are threatened, then my argument would not apply. Nor would my argument establish the desirability of judicial review to protect any structural constitutional norms not directly safeguarding fundamental rights (including norms of constitutional federalism). ${ }^{123}$ There is, I

action should have "a reasonably robust law of ultra vires ... that denies any legal effect to acts by a government official outside the bounds of authority granted the official by the law").

120 See, e.g., FCC v. Beach Commc'ns, Inc., 508 U.S. 307, 3I3 (I993) (explaining that "[i]n areas of social and economic policy, a statutory classification that neither proceeds along suspect lines nor infringes fundamental constitutional rights must be upheld against equal protection challenge if there is any reasonably conceivable state of facts that could provide a rational basis for the classification"); see also Richard H. Fallon, Jr., The Supreme Court 1996 Term-Foreword: Implementing the Constitution, I I HARV. L. REV. 54, 69 (I997) (describing how the "rational basis" test and other "[n]onsuspect-content tests call for judicial scrutiny pursuant to standards reflecting strong presumptions of constitutional validity").

121 Cf. Cross, supra note 4, at 1589 (arguing for a "one-way ratchet" whereby "whichever national institution provides the greatest protection of rights prevails").

122 The Supreme Court has recently engaged in close oversight of congressional efforts to "enforce" the Fourteenth Amendment based on its judgment that Congress may not define the Constitution's substantive guarantees more broadly than the Court has defined them. See City of Boerne v. Flores, 52 I U.S. 507, 5 I9 (I997) (holding that by attempting to provide more protection to free exercise rights than had the Supreme Court, Congress exceeded its Section 5 powers, since "[l]egislation which alters the meaning of the Free Exercise Clause cannot be said to be enforcing the Clause"). The Court once took a more relaxed approach, positing that Congress's powers under Section 5 mirrored the broad reach of its powers under the Necessary and Proper Clause as articulated in McCulloch v. Maryland, I7 U.S. (4 Wheat.) 3I6 (I8I9). See Katzenbach v. Morgan, 384 U.S. 64I, 65 I (I966) (holding that "the McCulloch v. Maryland standard is the measure of what constitutes 'appropriate legislation' under $\S 5$," which is "a positive grant of legislative power authorizing Congress to exercise its discretion in determining whether and what legislation is needed to secure the guarantees of the Fourteenth Amendment").

123 Cf. Jesse H. Choper, Judicial Review and the National Political Process (I980) (arguing that judicial review is appropriate in cases involving individual rights, but not in those involving federalism issues or the respective powers of Congress and the President). It is frequently argued that judicial review of separation-of-powers and federalism issues is appropriate because the ultimate purpose of the separation of powers and federalism is to protect rights. 
should hasten to add, nothing in my argument that precludes judicial review to enforce structural constitutional norms, but the case for judicial review in such cases would need to depend on other arguments than those that I have advanced.

A potentially even larger implication of supporting judicial review based on my argument, rather than on the alternative premise that courts are better than legislatures at identifying fundamental rights correctly, would come in cases in which claims of fundamental rights are plausibly (even if not correctly) asserted on both sides. For example, Congress might think certain "accommodations" of religious institutions or believers necessary to protect their fundamental right to religious freedom, whereas those burdened by an "accommodation" might contend that it violates their fundamental right not to be compelled to support religious practice or belief. ${ }^{124}$ Or a legislature might conclude that prohibitions against hate speech are necessary to afford vulnerable minority groups the equal protection of the laws, while opponents claim that a prohibition against hate speech interferes with the fundamental right to freedom of expression. ${ }^{125}$ In cases in which the legislature has striven conscientiously to determine which of two competing fundamental rights claims deserves to prevail, my argument which presupposes that legislatures are as likely as courts to decide correctly - implies that there is no good reason to want judicial review. The argument for preferring overenforcement to underenforce-

See, e.g., Clinton v. City of New York, $5_{24}$ U.S. 4I 7, 449-53 (I998) (Kennedy, J., concurring) (disputing the notion that separation-of-powers infringements do "not threaten the liberties of individual citizens"); Akhil Reed Amar, Of Sovereignty and Federalism, 96 YALE L.J. I425, I426 (I987) (arguing that federalism "is designed to protect, not defeat... individual rights"). But while judicial review of federalism and separation of powers questions plausibly helps to protect liberty in a general sense, such review is generally unnecessary to protect fundamental rights, and my multiple-veto-opportunities argument rests on the premise that fundamental rights have a claim to special judicial protection that other liberty interests do not under conditions of reasonable disagreement.

124 Cf. Corp. of the Presiding Bishop of the Church of Jesus Christ of Latter-Day Saints v. Amos, 483 U.S. 327 (I987) (upholding a federal law exempting religious organizations from an otherwise applicable prohibition against employment discrimination on the basis of religion even though the effect of this exemption was to allow employees to be dismissed based on their religious practices and beliefs).

125 Cf. R.A.V. v. City of St. Paul, 505 U.S. 377, 39I (I992) (striking down a city ordinance prohibiting bias-motivated crime because "[t]he First Amendment does not permit St. Paul to impose special prohibitions on those speakers who express views on disfavored subjects"); Am. Booksellers Ass'n, Inc. v. Hudnut, 77I F.2d 323, 329 (7th Cir. 1985) (declaring unconstitutional on free expression grounds a city's antipornography ordinance even while accepting the ordinance's premise that pornography that subordinates women "leads to affront and lower pay at work, insult and injury at home, [and] battery and rape on the streets"); Frank I. Michelman, Conceptions of Democracy in American Constitutional Argument: The Case of Pornography Regulation, 56 TENN. L. REV. 29I, 307-09 (I989) (noting Hudnut's refusal to balance the interest in free expression against the "women's claims to liberty and equal protection" infringed by unregulated pornography). 
ment of rights has no bite in genuinely zero-sum contests between competing claims of fundamental rights. ${ }^{126}$

Obviously, however, it may often be disputable whether a particular case does in fact involve a collision of rights or whether it would be reasonable to believe that a collision exists. It is far from obvious what the institutional mechanism for resolving such questions ought to be. One possible approach would have courts decide such issues at the threshold of every case and then decline further review if a collision between fundamental rights exists or could reasonably be thought to exist. Another approach would assume that actual collisions of fundamental rights are likely to occur so rarely, and that the task of distinguishing actual from purported collisions of fundamental rights is likely to be so conceptually complex and politically divisive, that courts should simply proceed to decide all cases involving claims of fundamental rights, even if it would be desirable in principle to withhold review in zero-sum cases. Division and resentment would seem inevitable if a court had to hinge its decision of a disputed question on the ground that the contentions of one side were not only mistaken, but also unreasonable. And an approach under which courts exercised judicial review in all disputed cases, even though the rationale for their doing so would not in principle apply universally, would accord with one of the assumptions on which I have said that my multiple-vetoopportunities defense of judicial review rests - that legislative action is more likely to violate fundamental rights than legislative inaction. Other possibilities are also imaginable.

Although my argument for judicial review does not directly mandate any single approach to cases involving claimed tensions between fundamental rights, my tentative judgment is that it would be best to have courts determine at the threshold whether a case could reasonably be thought to involve an actual collision of fundamental rights and, if so, either go no further or certify any decision on the merits as subject to legislative override. As I have said, when rights disputes could reasonably be thought to be zero-sum games, the best argument for judicial review runs out if legislatures are presumed to be as likely as courts to identify rights correctly.

126 See Cross, supra note 4, at I604-05 (arguing that a "multiple vetoes" rationale for judicial review identifies no comparative judicial advantage in cases involving conflicts of rights and that "difficult tradeoffs are best made by more majoritarian institutions"). A multiple vetoes argument also fails to support judicial review in any case in which there is reasonable disagreement concerning whether a single governmental action either violates an individual's fundamental rights or, to the contrary, is necessary to respect the fundamental rights of that very same person. This situation would exist if, for example, it was reasonable to believe that a partly race-based scheme of public school assignments was necessary to enforce a particular schoolchild's fundamental right to an education untainted by past public racism and that race-based assignments would violate the same child's fundamental right not to be stigmatized through treatment as a racial token. 


\section{B. Scope of Review}

In cases that could not reasonably be thought to involve zero-sum collisions of fundamental rights, every increment in the stringency of judicial scrutiny diminishes the risk that a constitutional right will be erroneously underenforced, but increases the likelihood of erroneous overenforcement. With the anticipated moral costs of these effects needing to be weighed against one another, there is no reason to assume that the same balance should prevail with respect to every fundamental right - any more under my rationale for judicial review than under a scheme of judicial review predicated on the assumption that courts possess a special competence for identifying rights correctly. In American constitutional law, for example, different fundamental rights are currently protected by a diverse array of tests. ${ }^{127}$ My proposed multiple-veto-opportunities rationale would easily support a similar diversity. It would also comport with the current judicial practice of propounding doctrinal tests that implement vague constitutional norms without necessarily reflecting their semantic meaning. ${ }^{128}$ To take perhaps the easiest, best known example, the Miranda ${ }^{129}$ rule calling for the exclusion of confessions from criminal trials unless suspects in police custody have received specified warnings does not precisely reflect the meaning of a constitutional norm forbidding coerced confessions. Rather, it implements that norm by establishing rules that are readily administrable by police and judges alike. ${ }^{130}$

My framing of the stakes in weighing the costs of anticipated overand underenforcement of fundamental rights does, however, put scopeof-review questions in a different light than do familiar discussions of how to trade off rights against competing governmental interests. In designing a system of judicial review, the question - as I have emphasized - is not solely one of how to weigh rights against other interests based on the supposition that we actually know what rights people have. Rather, the challenge is to determine the ultimate standard that a court should apply in determining whether to invalidate legislation when no initial baseline agreement concerning the content of rights exists and there is no reason to think courts better than legislatures at resolving disputed questions correctly. One question is how a court,

127 See Fallon, supra note I20, at 67-73 (providing a typology of "relatively common kinds of tests" adopted by the Court "to help define constitutional limits on governmental powers").

128 See generally RichaRd H. FAllon, JR., ImPlementing The CONSTITUtion 37-44 (200I) (developing the thesis that many constitutional tests are judicially constructed devices for implementing constitutional norms, not reflecting their original or semantic meanings); Berman, supra note 56.

129 Miranda v. Arizona, 384 U.S. 436 (ig66).

130 See Fallon, Judicially Manageable Standards and Constitutional Meaning, supra note 56, at I305-06. 
thinking independently, should determine how to define a fundamental right. Another closely related but separate question is whether a court should invalidate legislation whenever, in its independent judgment, a fundamental right has been violated or whether - under circumstances of reasonable disagreement - it should accord more or less deference to the legislature's determination. For a system-designer, the ultimate question has to be how to weigh the risks and costs of underenforcement against those of overenforcement when a court and the legislature, acting in presumptive good faith, reasonably disagree about whether a fundamental right has been violated.

Relatively deferential review is undoubtedly an option. Indeed, such review is probably a more attractive option when judicial review is predicated on the assumption that fundamental rights should be protected by multiple veto opportunities than if courts are thought more likely than legislatures to resolve disputed questions correctly.

\section{Choosing Strong or Weak Judicial Review}

A final, crucial design question is whether judicial review should be strong or weak. As should already be evident, however, strong and weak judicial review are not binary alternatives, but labels that mark areas along a spectrum; rights may be more or less entrenched, as may the guarantee of judicial review as a mechanism to enforce fundamental rights. ${ }^{131}$ The Constitution of the United States, for example, includes several varieties of entrenchment rules. Under Article V, the amendment of most constitutional rules requires approval by twothirds majorities in both houses of Congress and by legislatures or conventions in three-fourths of the states. ${ }^{132}$ But Article $\mathrm{V}$ also provides even more stringently "that no State, without its Consent, shall be deprived of its equal Suffrage in the Senate," and it once established absolutely that no amendment could be enacted barring the slave trade before $1808 . .^{133}$

My multiple-veto-opportunities argument in favor of judicial review implies that judicial decisions defining and enforcing fundamental rights ought to have some degree of invulnerability to override by ordinary legislation. But it is impossible to give an abstract specification of exactly where along the spectrum of possible degrees of entrenchment the optimal solution lies. There are too many interrelated

131 The most extreme form of entrenchment would purport to be absolute and to bind in perpetuity. By contrast, a very weak, if not the weakest, form would forbid displacement of a current norm by the ordinary majoritarian requirement of fifty percent of the legislature plus one, but permit displacement by a vote of fifty percent plus two.

132 U.S. CONST. art. V.

133 Id. 
variables. ${ }^{134}$ In a genuinely nonpathological society of the kind that Waldron imagines, only a mild form of entrenchment would seem to me to be desirable. Under conditions of reasonable disagreement, democratic institutions should not be too disabled from making periodic reassessments of where and how to strike the balance in weighing the comparative risks and moral costs of the over- and underenforcement of fundamental rights.

Once again, however, it cannot simply be taken for granted that a currently nonpathological society will remain that way, and entrenched judicial review may provide a stronger hedge against pathologies that might develop in the future. The desirability of relatively more or less entrenched judicial review may thus depend on the pathological proclivities, if any, of particular societies - even when no assumption is made that those proclivities are socially or politically dominant at a particular time.

\section{Judicial Review in Societies that Are Not Well Ordered}

Perhaps out of an excess of caution, I want to conclude this Part by reminding readers that my arguments with respect to constitutional design have all proceeded on the assumption that Waldron's four conditions are satisfied and, in particular, that the legislature is conscientiously committed to respecting individual rights. I have not purported to judge how fully the United States or any other society realizes the predicates on which Waldron's arguments and mine depend. Nor have I purported to assess how judicial review should be structured in societies in which the assumptions that I have followed Waldron in making are, to one or another extent, less than wholly satisfied.

I hope, however, that the importance of the subjects that I have not addressed will not create the impression that I, following Waldron, have not plowed rich ground. Too often American constitutional theorists have focused their analyses exclusively on how the Supreme Court of the United States should interpret the Constitution of the United States under current circumstances. The proper domain of constitutional theory is broader. Certainly it should encompass inquiries into what provisions for judicial review (if any) ought to exist in constitutions for all societies whose people and legislatures are seriously committed to respecting rights.

134 Among other things, the appropriate degree of entrenchment might depend on the scope of judicial review of legislative action. If, for example, courts operated under a scope-of-review formula that permitted them to invalidate legislation only in cases in which they thought that the legislature had made a "clear mistake" in finding no infringement of fundamental rights, then a stronger degree of entrenchment might be appropriate than if it were assumed that courts would exercise wholly independent judgment in identifying rights violations. 


\section{CONCLusion}

In this Article I have advanced parallel, substantially overlapping negative and positive theses. The negative thesis is that Jeremy Waldron's provocative arguments in The Core of the Case Against Judicial Review do not succeed. The positive thesis is that judicial review is reasonably defensible within the terms of liberal political theory, even for nonpathological societies, if, but only if, a number of assumptions are valid.

Waldron's core case against judicial review rests heavily on premises and arguments suggesting that courts may be no better than legislatures at resolving disputes about individual rights correctly. But the best outcome-based reason to support judicial review is one that Waldron overlooks. The affirmative case for judicial review need not depend on the assumption that courts can identify rights more accurately than legislatures. Rather, the most persuasive case maintains that both institutions should be enlisted in the cause of rights protection because it is morally more troublesome for fundamental rights to be underenforced than overenforced.

Waldron's affirmative case that judicial review is unfair and politically illegitimate also fails, and the arguments so demonstrating point once again to grounds of fairness and legitimacy on which judicial review can be affirmatively defended. The fairness and political legitimacy of procedural mechanisms depend on the ends that they serve. If judicial review is reasonably designed to improve the substantive justice of a society's political decisions by safeguarding against violations of fundamental rights, then it is not unfair, nor is it necessarily politically illegitimate. Political legitimacy can flow from multiple sources. Even insofar as judicial review lacks specifically democratic legitimacy, the democratic character of other elements of a political regime can partly compensate for this deficiency. And a shortfall in democratic legitimacy may ultimately be outweighed, as a matter of overall legitimacy, by the contribution that judicial review can make to the protection of individual rights.

In concluding, however, I must emphasize once more that the arguments for judicial review that I have advanced in this Article are qualified and contingent in several ways. The case for judicial review depends on a number of premises that seem to me likely to be true and that Waldron has not refuted, but that would be difficult and in some cases perhaps impossible to establish with knock-down, rationally irresistible arguments. Some of these premises are moral or conceptual, others empirical. Among the important but contestable premises undergirding my case for judicial review are that even if courts are not better overall at identifying rights violations than are legislatures, courts have a perspective that makes them more likely to apprehend serious risks to some kinds of fundamental rights; that errors that re- 
sult in the violation of fundamental rights are typically more morally disturbing than errors that result in the erroneous overenforcement of fundamental rights; and, perhaps most crucially, that a system of judicial review can be so designed that the total moral costs of the overenforcement of rights that judicial review would likely produce will be lower than the moral costs that would result from the underenforcement that would occur in the absence of judicial review. Any philosophical case for judicial review, and probably against it as well, needs to depend on reasonable, but also perhaps reasonably contestable, premises such as these. This is an important point in its own right, with which debate about judicial review needs to come to grips. 